\title{
Dexamethasone represses cAMP rapid upregulation of TRH gene transcription: identification of a composite glucocorticoid response element and a cAMP response element in TRH promoter
}

\author{
A Cote-Vélez*, L Pérez-Martínez*, M Y Díaz-Gallardo, C Pérez-Monter, \\ A Carreón-Rodríguez, J-L Charli and $\mathrm{P}$ Joseph-Bravo \\ Departamento de Genética del Desarrollo y Fisiología Molecular, Instituto de Biotecnología, Universidad Nacional Autónoma de México, AP 510-3, Cuernavaca, Mor. 62250, \\ México
}

(Requests for offprints should be addressed to P Joseph-Bravo; Email: joseph@ibt.unam.mx)

*(A Cote-Vélez and L Pérez-Martínez contributed equally to this work)

\begin{abstract}
Hypothalamic proTRH mRNA levels are rapidly increased (at $1 \mathrm{~h}$ ) in vivo by cold exposure or suckling, and in vitro by $8 \mathrm{Br}$-cAMP or glucocorticoids. The aim of this work was to study whether these effects occurred at the transcriptional level. Hypothalamic cells transfected with rat TRH promoter $(-776 /+85)$ linked to the luciferase reporter showed increased transcription by protein kinase (PK) A and PKC activators, or by dexamethasone (dex), but co-incubation with dex and 8Br-cAMP decreased their stimulatory effect (as observed for proTRH mRNA levels). These effects were also observed in NIH-3T3-transfected cells supporting a characteristic of TRH promoter and not of hypothalamic cells. Transcriptional regulation by $8 \mathrm{Br}$-cAMP was mimicked by noradrenaline which increased proTRH mRNA levels, but not in the presence of dex. PKA inhibition by $\mathrm{H} 89$ avoided 8Br-cAMP or noradrenaline stimulation. TRH promoter sequences, cAMP response element (CRE)-like (-101/-94 and -59/-52) and glucocorticoid response element (GRE) half-site (-210/-205), were analyzed by electrophoretic mobility shift assays with nuclear extracts from hypothalamic or neuroblastoma cultures. PKA stimulation increased binding to CRE $(-101 /-94)$ but not to CRE (-59/-52); dex or 12-O-tetradecanoylphorbol-13-acetate (TPA) increased binding to GRE, a composite site flanked by a perfect and an imperfect activator protein (AP-1) site in the complementary strand. Interference was observed in the binding of CRE or GRE with nuclear extracts from cells co-incubated for $3 \mathrm{~h}$ with $8 \mathrm{Br}$-cAMP and dex; from cells incubated for $1 \mathrm{~h}$, only the binding to GRE showed interference. Rapid cross-talk of glucocorticoids with PKA signaling pathways regulating TRH transcription constitutes another example of neuroendocrine integration.
\end{abstract}

Journal of Molecular Endocrinology (2005) 34, 177-197

\section{Introduction}

Thyrotropin-releasing hormone (TRH), synthesized in the paraventricular nucleus of the hypothalamus (PVN) and released from the median eminence, regulates the pituitary-thyroid axis; other endocrine functions include its effects on the synthesis and release of prolactin (de Greef et al. 1987, Segerson et al. 1987 a, Haisenleder et al. 1992, Lechan \& Toni 1992, Fink et al. 1993). TRH gene expression in the PVN is strictly controlled by the feedback action of thyroid hormones (Koller et al. 1987, Segerson et al. 1987b, Rondel et al. 1988, Hollenberg et al. 1995, Satoh et al. 1999) and is regulated in multiple physiological conditions including: circadian and estrous cycles (Covarrubias et al. 1988, Uribe et al. 1991), suckling and weaning (Uribe et al. 1993, 1995b, Sánchez et al. 2001), cold stress (Zoeller et al. 1990, Uribe et al. 1993, Sánchez et al. 2001) and fasting (Blake et al. 1991, Legradi et al. 1997a, Fekete et al. 2002). In addition, a fast and transient increase in proTRH mRNA levels in the PVN (maximal at 30-60 min) is produced by cold exposure or suckling (Uribe et al. 1993, Sánchez et al. 2001), conditions that activate TRH release from the median eminence (Arancibia et al. 1983, de Greef et al. 1987, Rondel et al. 1988).

At the transcriptional level, the negative feedback of thyroid hormones is well characterized (Segerson et al. 1987b, Hollenberg et al. 1995, Satoh et al. 1996, Guissouma et al. 2000, Abel et al. 2001) and the consensus sequences for thyroid hormone receptor (TR) binding identified in the human (h) (Yamada et al. 1990), rat (r) (Lee 1988) and mouse (m) (Abel et al. 2001) TRH genes. The sequence between -547 to +84 of rTRH promoter confers almost full basal transcriptional activity in transfected cells (Balkan et al. 1998); within this sequence, response elements of the transcriptional factors: activator protein 1 (AP-1), cAMP response element (CRE)-binding protein (CREB), and glucocorticoid 
receptors (GR) are present in the three species. Two DNA elements similar to consensus CRE are localized in the rTRH gene $(-101 /-94$ (CRE-2) and $-59 /-52$ (CRE-1)). CRE-1 (TGACCTCA) (also called site 4) binds CREB (Hollenberg et al. 1995, Wilber \& Xu 1998, Harris et al. 2001) and overlaps a thyroid hormone response element (THRE (AGGTCA)), recognized as an important site for thyroid hormone negative feedback in the three species (Hollenberg et al. 1995, Satoh et al. 1996, 1999). The stimulatory role of CREB on TRH gene transcription has been evidenced in cells transfected with constructs including human or murine TRH promoters (Wilber \& Xu 1998, Harris et al. 2001); 8-h incubation with $\alpha$-melanocyte stimulating hormone ( $\alpha \mathrm{MSH}$; which increases phosphorylated CREB (PCREB) (Sakar et al. 2002)) enhances TRH transcription (Harris et al. 2001). The stimulatory effect of $\alpha \mathrm{MSH}$ is reduced in the presence of 3,5,3'-triiodothyronine $\left(\mathrm{T}_{3}\right)$ and transfected thyroid hormone receptor TR $\beta 2$ (Harris et al. 2001).

The effects of glucocorticoids on TRH gene expression are less well understood. A stimulatory effect of long-term treatment (days) with dexamethasone (dex) on proTRH mRNA levels was first described in CA77 cells (Tavianini et al. 1989), and later in rat anterior pituitary or in diencephalic primary cultures (Bruhn et al. 1994, Luo et al. 1995). Primary cultures of hypothalamic cells have a time- and dose-dependent response to dex: a rapid increase of proTRH mRNA levels (1-3 h) occurs at $10^{-6}$ to $10^{-8} \mathrm{M}$ while levels are diminished at $10^{-10} \mathrm{M}$ or after 24-h incubation at $10^{-8} \mathrm{M}$ (Joseph-Bravo et al. 1998, Pérez-Martínez et al. 1998). In vivo, glucocorticoids have an inhibitory influence (Kakucska et al. 1995) suggested to be due to their inhibitory effect on CREB phosphorylation in the PVN (Legradi et al. 1997a); upregulation of P-CREB levels follows glucocorticoid depletion (Whitehead \& Carter 1997a). Rat TRH promoter lacks a canonical glucocorticoid response element (GRE) but has several copies of the strongest half-site (TGTTCT) (Dahlman-Wright et al. 1991) at: - 735, -560 or -210 , and a near-consensus inverted site at -284 (GGTCCAcacTCT TGT), as well as two other inverted half-sites at -275 and -310 (Lee 1988). Site $-210 /-205$ binds GR (Lee et al. 1996). Hela cells transfected with the plasmid containing the $-242 /+84$ sequence of rTRH promoter, or with deletions of a cis-acting element located between -242/-200, proved that this region is important for basal transcription and glucocorticoid response (Lee et al. 1996). Pancreatic cells transfected with rTRH promoter fragments $-554 /+84$ or $-242 /+84$, treated for $48 \mathrm{~h}$ with dex, showed increased transcriptional activity (Fragner et al. 2001). (See Fig. 1 for the position of putative response elements in the rTRH promoter).

Since most of the in vivo or in vitro studies on TRH gene regulation have dealt with long-term treatments (at least $6 \mathrm{~h}$ ) in various cell types, the role of the regulatory elements involved in a fast neuronal response has yet to be characterized. We have previously shown that proTRH mRNA levels are rapidly increased $(1-3 \mathrm{~h})$ in rat fetal hypothalamic primary cell cultures by PKA activators or by $10^{-8} \mathrm{M}$ dex; 12-Otetradecanoylphorbol-13-acetate (TPA) increases proTRH mRNA levels only after $2 \mathrm{~h}$ (Uribe et al. 1995a). However, co-incubation of 8Br-cAMP with either dex or TPA reduces their stimulatory effect while the effect of dex with TPA is additive (Pérez-Martínez et al. 1998). The aim of this study was to elucidate if the cross-talk between glucocorticoids and the PKA pathway occurred at the transcriptional level and to determine the possible involvement of the postulated CRE and GRE elements of the proTRH promoter. We report that PKA and GR signaling pathways rapidly regulated TRH gene transcription and that noradrenaline (NA), a mediator of cold stimulus (Arancibia et al. 1989), mimicked cAMP effects. Characterization of the elements that could mediate these effects demonstrated that CRE-2 ( $-101 /$ -94) could be an important target for TRH transcriptional regulation; this is also the case for GRE $(-210 /-205)$, which binds GR and has the characteristics of a composite GRE (Miner \& Yamamoto 1992, Harrison et al. 1995, Malkoski \& Dorin 1999).

\section{Materials and methods}

\section{Animals}

Wistar rats raised in the local vivarium were kept in a ratio of $12 \mathrm{~h}$ light: $12 \mathrm{~h}$ darkness and were allowed to feed ad libitum. Care was taken to preserve adequate conditions following the FRAME guidelines and as approved by the institute's ethical commission.

\section{Reagents}

Poly-D-lysine, dex, 8Br-cAMP, TPA, the PKA inhibitor H89 and its inactive form H85, dithiothreitol, glucose, glutamine, cytosine arabinofuranoside and DNAse were from Sigma. Poly (dI-dC), dNTPs and luciferase assay kit were from Roche; thyroxine $\left(\mathrm{T}_{4}\right)$ polynucleotide kinase was from Promega. Dulbecco's modified Eagle's medium (DMEM), Hank's medium, trypsin, fetal bovine serum, vitamins and antibiotic-antimycotic were from GIBCO; guanidinium thiocyanate was from Fluka Steinheim (Sigma) and $\left[{ }^{32} \mathrm{P}\right] \mathrm{ATP}$ from NEN Life Science Products (Boston, MA, USA). Expression vectors for CREB (SV-GREB) (González et al. 1989), AP-1 (c-Jun (RSV-cJun), c-Fos (RSV-cFos)) (Hirai et al. 1990, Schontal et al. 1988) and GR (CEO-GR) (Meyer et al. 1989) were a kind gift from Dr Gustavo Pedraza-Alva, IBT-UNAM; TRH-Luc plasmid was a gift from Dr Wayne Balkan, University of Miami School 
of Medicine, Miami, FL, USA. Oligonucleotides with the consensus and mutant CRE and AP- 1 sequences and antibodies used in supershift analysis were purchased from Santa Cruz Biotechnology (Santa Cruz, CA, USA). Other oligonucleotides described in this work were synthesized at the institute.

\section{Cell culture}

Primary cultures of hypothalamic cells were performed as described previously (Joseph-Bravo et al. 2002) using embryos from anesthetized pregnant Wistar rats on the 17 th day of gestation. Cells were plated on $1.5 \mu \mathrm{g} / \mathrm{ml}$ poly-D-lysine pre-coated $35 \mathrm{~mm}$ plates $\left(2 \cdot 7 \times 10^{6}\right.$ cells for TRH release studies, electrophoretic mobility shift assays (EMSAs) and transient transfection assays); for proTRH mRNA quantification, $0.6 \times 10^{6}$ cells were plated in $16 \mathrm{~mm}$ plates. DMEM was supplemented with $10 \%$ fetal calf serum (FCS), $0.25 \%$ glucose, $2 \mathrm{mM}$ glutamine, $3.3 \mu \mathrm{g} / \mathrm{ml}$ insulin, $1 \%$ antibiotic-antimycotic and $1 \%$ vitamin solution (S-DMEM). Cultures were maintained at $37^{\circ} \mathrm{C}$ with $7 \% \mathrm{CO}_{2}, 93 \%$ air atmosphere and $90 \%$ humidity. On the fourth day in vitro (DIV), cytosine arabinofuranoside $\left(10^{-5} \mathrm{M}\right)$ was added and mantained for $48 \mathrm{~h}$ to inhibit cell proliferation; afterwards half the incubation medium was replaced every second day with fresh S-DMEM (Charli et al. 1995). When drugs were dissolved in dimethyl sulfoxide (DMSO) (dex or TPA), an equivalent DMSO concentration was added to controls.

NIH-3T3 cells were maintained in DMEM supplemented with $10 \% \mathrm{FCS}$ at $37{ }^{\circ} \mathrm{C}$ with $7 \% \mathrm{CO}_{2}, 93 \%$ air atmosphere, and 90\% humidity.

The SH-SY5Y (ATCG CRL-2266) neuroblastoma cell line was kindly donated by Dr Rosa Ma Pardós (Instituto de Fisiología, Benemérita Universidad Autónoma de Puebla, México). Cells were grown in $125 \mathrm{ml}$ flasks to confluency in S-DMEM, then rinsed with Hank's medium, trypsinized (4 min, with $5 \mathrm{ml}$ of trypsin), centrifuged (5 min) and the pellet was resuspended in S-DMEM. For experiments with undifferentiated cells, $7 \times 10^{6}$ cells were seeded in $60 \mathrm{~mm}$ plates and incubated for $24 \mathrm{~h}$. Differentiated cells were obtained by seeding $5 \times 10^{6}$ cells in $60 \mathrm{~mm}$ plates, incubating them for $24 \mathrm{~h}$ and replacing the medium with S-DMEM containing 5\% FCS and $1.6 \times 10^{-9} \mathrm{M}$ TPA; half the medium was replaced every 2 days for 8 days (Renauld \& Spengler 2002).

\section{Transient transfection and luciferase assays}

Hypothalamic cultures from 12 DIV were transiently transfected using polyethylenimine (Guerra-Crespo et al. 2003). Transfections were carried out in $35 \mathrm{~mm}$ dishes with $2 \cdot 7 \times 10^{6}$ hypothalamic cells, $5 \mu \mathrm{g}$ of a reporter plasmid containing rat TRH promoter $(-776 /+85)$ linked to the luciferase reporter (TRH-Luc) and $5 \mu \mathrm{g}$ RSV- $\beta$-gal (Gynheung et al. 1982) used as internal control of transfection efficiency. Cells were cultured for $48 \mathrm{~h}$ in S-DMEM and then harvested for luciferase activity (following kit instructions) and $\beta$-galactosidase activity (Lucibello et al. 1990). Luciferase values were normalized to values obtained for $\beta$-galactosidase activity and protein content; data are expressed relative to luciferase activity.

NIH-3T3 cells were plated in $35 \mathrm{~mm}$ dishes and grown for 20-24 h to a confluency of around $60 \%$. The cells were then transfected with polyethylenimine. Cotransfection was performed with $1 \mu \mathrm{g}$ transcription factor expression vector(s) together with $5 \mu \mathrm{g}$ reporter plasmid (TRH-Luc), $3 \mu \mathrm{g}$ pRSV- $\beta$-gal and PUC18 to a total of $10 \mu \mathrm{g}$ plasmid DNA per dish. Cells were cultured for $48 \mathrm{~h}$ in DMEM with 10\% FCS; then treated for $3 \mathrm{~h}$ with $8 \mathrm{Br}$-cAMP, TPA or dex and harvested for luciferase activity. Data are expressed as relative luciferase activity with respect to cells transfected only with TRH-Luc. For EMSAs, NIH-3T3 cells were transfected with $1 \mu \mathrm{g}$ of the expression vector (CREB, AP-1 or GR) together with $3 \mu \mathrm{g}$ pRSV- $\beta$-gal and PUC18 to a total of $10 \mu \mathrm{g}$ plasmid DNA per dish.

\section{Determination of TRH content and release by RIA}

Hypothalamic primary cells (18 DIV) were incubated with drugs diluted in DMEM at concentrations and times stated in the figures. The medium was collected in a tube and immediately frozen; cells were stored at $-20^{\circ} \mathrm{C}$. TRH cell content was extracted as described previously (Joseph-Bravo et al. 2002). It was not possible to measure TRH directly in the culture medium due to interference in the RIA; therefore, the medium was thawed and extracted with C-18 cartridges (Sep-pak, Millipore) activated according to the manufacturer's specifications; TRH was eluted with $60 \%$ methanol after washing with $2 \mathrm{ml}$ water. The methanol extract was evaporated and the residue was resuspended in $250 \mu \mathrm{l}$ $0.05 \mathrm{M}$ phosphate buffer, $\mathrm{pH} 7 \cdot 5,0.25 \% \mathrm{BSA}$ and immunoreactive TRH measured in duplicate by a specific RIA (Charli et al. 1995); Sep-pak-extracted medium included in the standard curve did not interfere with the RIA; recovery of $100 \mathrm{pg}$ TRH (Peninsula, Belmont, CA, USA) added before extraction was $>90 \%$ (not shown).

\section{mRNA purification}

Total RNA was extracted from frozen cells scraped with $4 \mathrm{M}$ guanidinium thiocyanate, $25 \mathrm{mM}$ sodium citrate, $\mathrm{pH} 7 \cdot 0,0 \cdot 5 \%$ sarcosyl, $0 \cdot 1 \mathrm{M} \beta$-mercaptoethanol as described previously (Pérez-Martínez et al. 1998). 
A

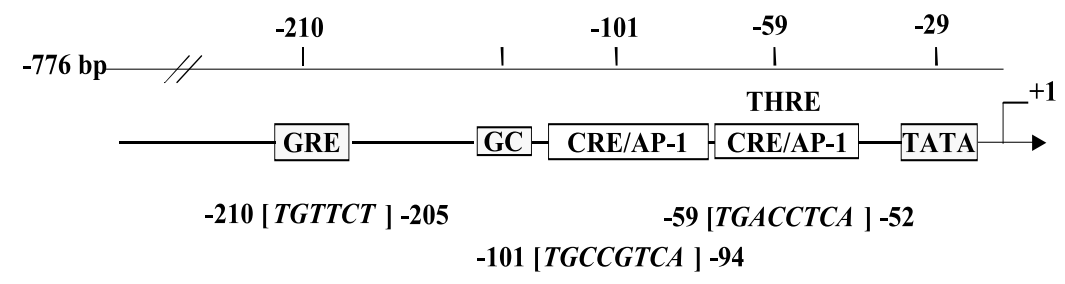

B

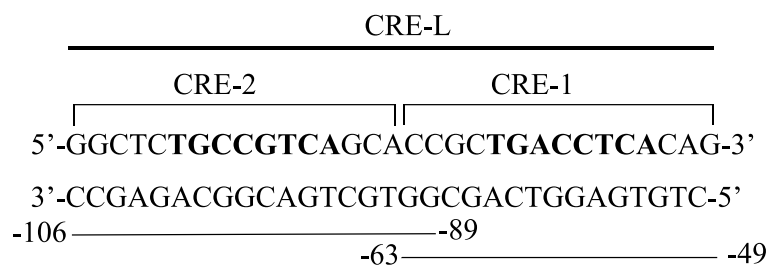

$\frac{\text { GRE-L }}{\text { GRE-A }}$
5'-CCTAGTCAGATGTTCTCTTAGTCAACAGA-3'
3'-GGATCAGTCTACAAGAGAATCAGTTGTCT-5',
-220-1

Figure 1 Regulatory elements of the rat TRH promoter region and oligonucleotides used in the EMSA. (A) Nucleotide positions are relative to transcription start site; potential regulatory elements are shown in boxes. Two putative overlapping AP-1 and cAMP response elements (CRE) are located from nucleotide position -59 to -52 (CRE-1) and from -101 to -94 (CRE-2). A half-palindrome sequence for THRE overlaps the CRE/AP-1 element at position $-59 /-52$. The GRE half-palindrome is located from -210 to -205 . (B) Sequences utilized as probes for EMSA analysis. CRE-L, CRE-1 and CRE-2 with CRE sites in bold. GRE site (shown in bold) and in the complementary strand, two AP-1 sites (bold and underlined).

\section{ProTRH mRNA semi-quantification by RT-PCR}

Reaction conditions for proTRH mRNA quantification were as previously reported (Perez-Martinez et al. 1998) except that $11 \mathrm{pmol}$ proTRH and $25 \mathrm{pmol}$ glyceraldehyde-3-phosphate dehydrogenase (G3 PDH) primers were used for co-amplification (30 cycles). Gels were analysed by laser densitometry to calculate the relative amounts of proTRH vs G3 PDH cDNAs.

\section{Nuclear extract preparation}

Hypothalamic cells (14 DIV), transfected NIH-3T3 cells or SH-SY5Y neuroblastoma cells were washed with PBS before obtaining nuclear extracts, as described previously (Schreiber et al. 1989) but with the following modifications: cells were lysed by 5 min incubation at $4{ }^{\circ} \mathrm{C}$ in hypotonic buffer $(10 \mathrm{mM}$ Tris- $\mathrm{HCl}, \mathrm{pH} 7 \cdot 6$, $10 \mathrm{mM} \mathrm{NaCl}, 1.5 \mathrm{mM} \mathrm{MgCl}, 0.5 \mathrm{mM}$ EDTA, $1 \mathrm{mM}$ dithiothreitol, $1 \mu \mathrm{g} / \mathrm{ml}$ leupeptin, $0.5 \mathrm{mM}$ phenylmeth- ylsulfonyl fluoride and $0 \cdot 6 \% \mathrm{NP}-40)$. Intact nuclei were washed with lysis buffer and nuclear extracts were obtained by incubating the nuclei in extraction buffer (20 mM Tris-HCl, pH $8.0,450 \mathrm{mM} \mathrm{KCl}, 0.5 \mathrm{mM}$ EDTA, $1 \mathrm{mM}$ dithiothreitol, $1 \mu \mathrm{g} / \mathrm{ml}$ leupeptin, $5 \mathrm{mM}$ spermidine and $25 \%$ glycerol) for 45 min under constant mild agitation at $4{ }^{\circ} \mathrm{C}$. DNA was eliminated by centrifugation for $15 \mathrm{~min}$ at $13000 \mathrm{~g}$. Protein content was determined by the Bradford assay (Bradford 1976).

\section{Electrophoretic mobility shift assay (EMSA)}

The double-stranded rat TRH promoter oligonucleotides used in EMSAs were as follows. CRE-L, containing the two potential CRE elements of the TRH promoter $(-101$ to -94 and -59 to -52$)$ : CRE-1, - 59/ - 52; CRE-2, - 101/ - 94. For GRE: GRE-L, -220/-193; GRE-A, - 215/-193. The sequences of double-stranded oligonucleotides used in EMSAs are 
depicted in Fig. 1. Other probes used were: CRE consensus, 5'-AGA GAT TGC GTG AGG TGA GAG AGG TAG-3'; GRE mutant, 5'-AGA GAT TGC CTG TGG TCA GAG AGG TAG-3'; GR consensus, 5'-GAC CCT AGA GGA TCT GTA CAG GAT GTT CTA GAT-3'; GR mutant, 5'- GAC CGT AGA GGA TCT GAA CAG GAT GTT CTA GAT-3'; STAT, 5'-CTC CTA TTG GCT TGA-3' (mutated bases in bold). EMSAs were conducted as described previously (Pedraza-Alva et al. 1994). Briefly, oligonucleotides were end-labeled with $\mathrm{T} 4$ polynucleotide kinase using $30 \mu \mathrm{Ci}$ $\left[\gamma-{ }^{32} \mathrm{P}\right] \mathrm{ATP} / 100 \mathrm{ng}$ of oligonucleotide. Nuclear extracts $(10 \mu \mathrm{g})$ were incubated for $20 \mathrm{~min}$ at room temperature with the labeled oligonucleotide $\left(1 \times 10^{5}\right.$ c.p.m. $)$ in band shift buffer (25 mM Hepes, pH 7.9, $40 \mathrm{mM} \mathrm{KCl}$, $3 \mathrm{mM} \mathrm{MgCl}, 0 \cdot 1 \mathrm{mM}$ EDTA, $1 \mathrm{mM}$ dithiothreitol and $10 \%$ glycerol) containing $1 \mu \mathrm{g}$ poly $(\mathrm{dI}-\mathrm{dC})$ as a non-specific competitor. DNA-protein complexes were resolved by electrophoresis on non-denaturing $6 \%$ polyacrylamide gels for $2-3 \mathrm{~h}$ at $150 \mathrm{~V} \quad(50 \mathrm{mM}$ Tris-HCl, $45 \mathrm{mM}$ boric acid, $0.5 \mathrm{mM}$ EDTA). They were analyzed either directly with a phosphor-imager (Molecular Dynamics, Piscataway, NJ, USA) or by film autoradiography (Fluor-S MultiImager; BioRad, Hercules, CA, USA).

For competition experiments, 10- to 100-fold molar excess of unlabeled oligonucleotide was added $5 \mathrm{~min}$ before adding the labeled probe. For immune band shift assays, $1 \mu \mathrm{g}$ antibody was incubated with nuclear extracts $\left(5 \mathrm{~h}\right.$ at $\left.4{ }^{\circ} \mathrm{C}\right)$ and then with labeled oligonucleotide. The same amount of an irrelevant antibody (rabbit IgG) or normal rabbit serum (NRS) was used as control. DNA-protein complexes were resolved by electrophoresis on $5 \%$ polyacrylamide gels.

\section{Statistical analysis}

Results were calculated as percentages of controls of each culture; data were then calculated as the means \pm S.E.M. Data were analyzed by ANOVA, considered significant at $P<0 \cdot 001$, followed by Fisher's PLSD test ( $P$ values stated in each figure).

\section{Results}

\section{Involvement of PKA in regulating proTRH mRNA levels}

To verify if the upregulation of proTRH mRNA levels by 8Br-cAMP (Pérez-Martínez et al. 1998) was due to PKA activation, we studied the effect of inhibiting PKA by preincubating $(30 \mathrm{~min})$ hypothalamic cells with $50 \mathrm{nM}$ H89. As shown in Fig. 2, $1 \mathrm{mM}$ 8Br-cAMP increased proTRH mRNA levels and this effect was avoided with H89; the presence of H89 revealed a dex stimulatory effect. As previously shown (Pérez-Martínez

\section{Hypothalamic cells}

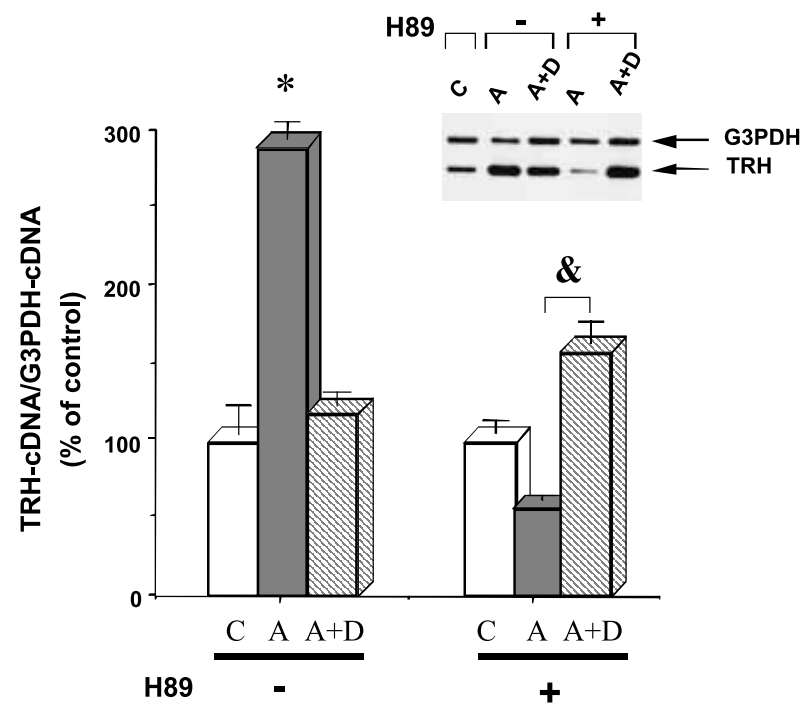

Figure 2 PKA mediated 8Br-cAMP upregulation of proTRH mRNA levels in hypothalamic cells. Primary cultures of fetal hypothalami were preincubated at 14 DIV with $50 \mathrm{nM} \mathrm{H89}$ for $30 \mathrm{~min}$, followed by $1 \mathrm{~h}$ incubation with $1 \mathrm{mM} 8 \mathrm{Br}$-cAMP (A), with or without $10 \mathrm{nM}$ dex (D). Total RNA was extracted and the levels of proTRH mRNA semi-quantified by RT-PCR. Values are expressed as the ratio of TRH/G3 PDH cDNA signal as a percentage of controls (100\%). $n=15 ;{ }^{*} P<0.001$ vs control; \&, $P<0.001$ between groups, by Fisher's PLSD).

et al. 1998), $10 \mathrm{nM}$ dex reduced the stimulation caused by PKA activation (Fig. 2).

\section{Rapid modulation of TRH transcription}

Hypothalamic cells from E17 rat embryos were transiently transfected with TRH-Luc (Balkan et al. 1998) to study whether the upregulation of proTRH mRNA levels by 8Br-cAMP, TPA or dex (PérezMartínez et al. 1998) occurred at the transcriptional level. Luciferase activity was increased after treatment with $8 \mathrm{Br}$-cAMP when compared with untreated cells but the increase by dex was not significant; co-treatment with $8 \mathrm{Br}$-cAMP and dex resulted in a reduction of the 8Br-cAMP-induced luciferase activity (Fig. 3A). These stimulatory and interference effects coincided with the reported variations in proTRH mRNA levels indicative of transcriptional effects. In contrast, although TPA increases proTRH mRNA levels after 2-3 h incubation and co-incubation with dex has additive effects (Uribe et al. 1995a, Pérez-Martínez et al. 1998), this was not significant in luciferase activity (Fig. 3A). The short time after which luciferase activity was assayed $(3 \mathrm{~h})$ could be insufficient for adequate c-Fos expression. 


\section{Hypothalamic cells}

A

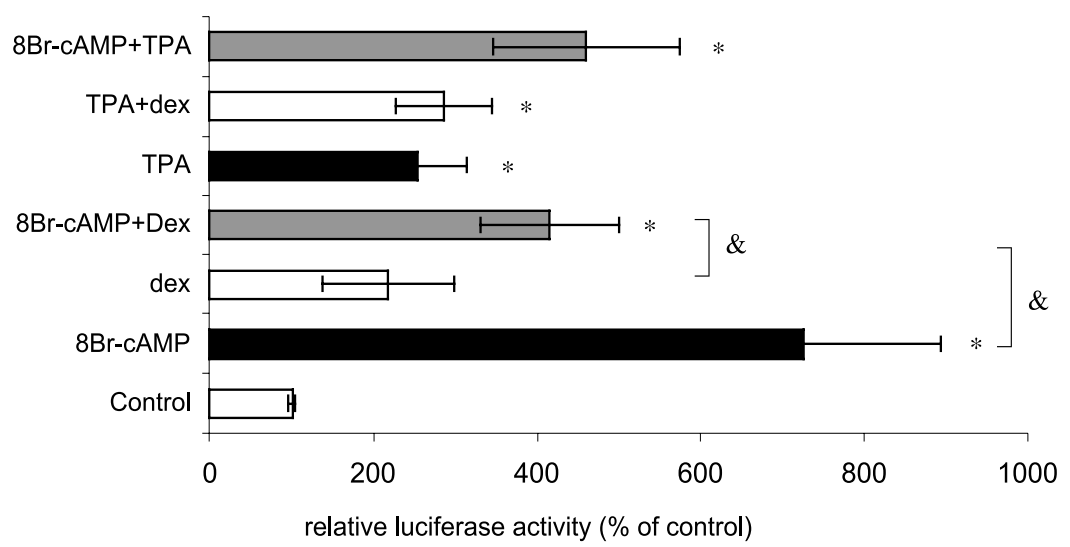

B

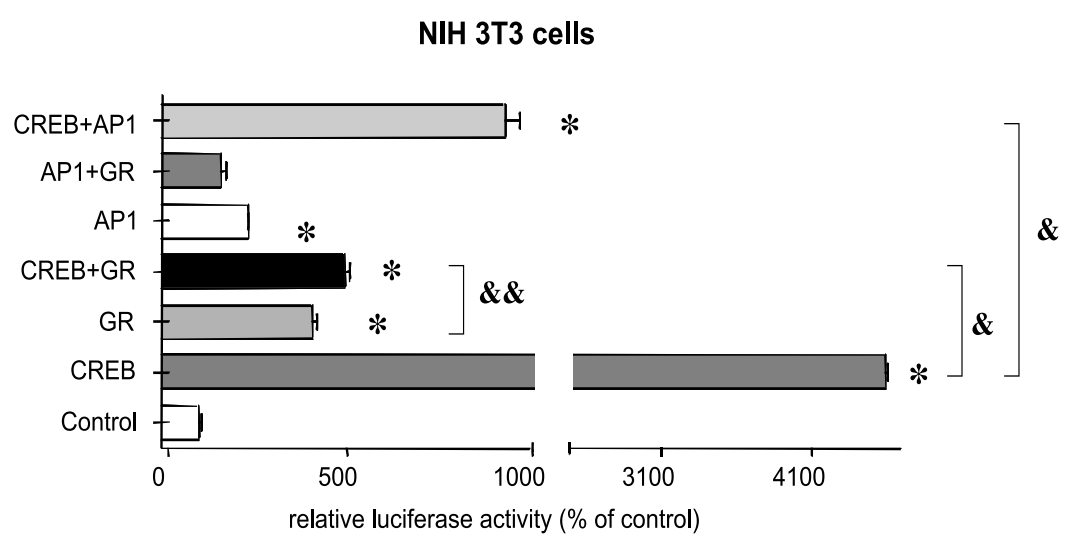

Figure $3 \mathrm{TRH}$ promoter activity was regulated by different signaling pathways. (A) Cultured hypothalamic cells (12 DIV) were transiently transfected with $5 \mu \mathrm{g}$ reporter plasmid (TRH-Luc) and RSV- $\beta$-gal as described in Materials and methods; $48 \mathrm{~h}$ after transfection, cells were stimulated with $1 \mathrm{mM}$ 8Br-cAMP, $100 \mathrm{nM}$ TPA, $10 \mathrm{nM}$ dex, alone or in combination. Total cell extracts were prepared $3 \mathrm{~h}$ after treatment and luciferase activity determined. Luciferase values were normalized to those obtained for $\beta$-galactosidase activity and protein content; results are plotted as a percentage of control cultures. Data are from six independent experiments with duplicate plates in each $(n=6)$. ${ }^{\star} P<0.01$ vs control; \&, $P<0.01$ between groups. (B) NIH-3T3 cells transfected with TRH-Luc, RSV- $\beta$-gal (control) and with plasmids expressing CREB, GR, or c-Fos and c-Jun, alone or combined; $48 \mathrm{~h}$ after transfection cells were stimulated with 8Br-cAMP $(1 \mathrm{mM})$, TPA $(100 \mathrm{nM})$, or dex $(10 \mathrm{nM})$, alone or in combination according to the cotransfected plasmid. Total cell extracts were prepared and luciferase activity determined as in panel $\mathrm{A}$. Results are the mean of luciferase values normalized against $\beta$-galactosidase activity and calculated as a percentage of controls of three independent experiments ( $n=6 ;{ }^{*} P<0.0001$ vs control; \&, $P<0.0001$ between groups; \&\&, $P<0.05$ between groups).

To determine whether transcription factors activated by PKA, PKC or glucocorticoid pathways can regulate the TRH promoter $(-776 /+85)$, a heterologous system was used. NIH-3T3 cells were cotransfected with TRH-Luc and expression vectors for either CREB, AP-1 (c-Fos and c-Jun), or GR and later incubated for $3 \mathrm{~h}$ with $8 \mathrm{Br}$-cAMP, TPA or dex respectively. Some cultures were cotransfected combining CREB and AP-1 or GR vectors and stimulated with $8 \mathrm{Br}-\mathrm{cAMP}+\mathrm{TPA}, 8 \mathrm{Br}-$ cAMP+dex, or TPA+dex, according to the combinations of vectors transfected. CREB expression and $3 \mathrm{~h}$ of stimulation with 8Br-cAMP increased luciferase activity compared with unstimulated cultures transfected only with TRH-Luc (Fig. 3B). Luciferase activity was reduced when GREB was co-expressed with either GR or AP-1 and incubated with $8 \mathrm{Br}-\mathrm{cAMP}+\mathrm{dex}$ or 8Br-cAMP+TPA respectively (Fig. 3B). Therefore, the interference between CREB and GR or AP-1 pathways occurred at the transcriptional level, independent of the cellular context. Expression of the GR or AP-1 and $3 \mathrm{~h}$ stimulation with either dex or TPA augmented luciferase activity only slightly compared with controls (Fig. 3B). 
TRH content and release in hypothalamic cells

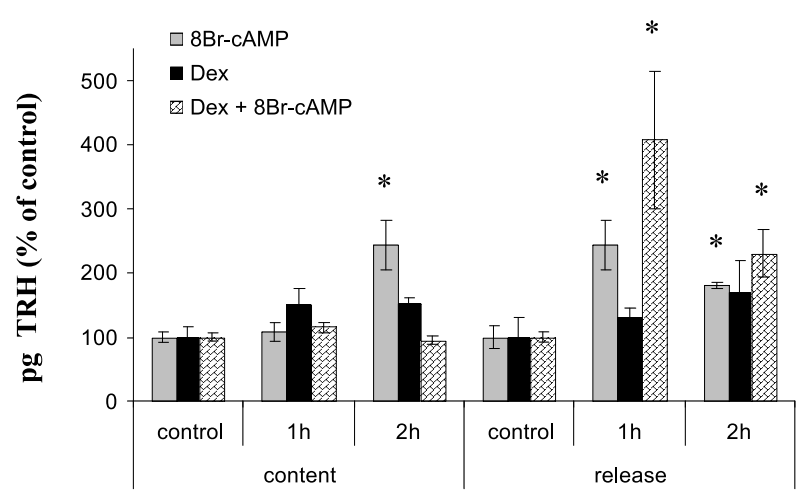

Figure 4 Effect of dex and PKA or PKC activators on TRH content and release from hypothalamic cells. Hypothalamic cells (18 DIV) were incubated for 1 or $2 \mathrm{~h}$ with $8 \mathrm{Br}$-cAMP $(1 \mathrm{mM})$ or dex $(10 \mathrm{nM})$, alone or in combination. Cells were extracted with $0.1 \mathrm{M}$ acetic acid-methanol $60 \%$, centrifuged and the supernatant evaporated and resuspended in RIA buffer for TRH quantification. The medium was extracted through Sep-pak cartridges and TRH quantified by RIA. Results are expressed as a percentage of controls of each culture. TRH cell content of controls from a representative culture: $257 \pm 19 \mathrm{pg}$; TRH in medium of controls: $31 \pm 3 \mathrm{pg}(n=16$; ${ }^{\star} P<0.05$ vs controls).

These effects were inhibited when GR and AP-1 were co-expressed in NIH-3T3 cells and stimulated simultaneously, in contrast to the effects of dex+TPA observed in hypothalamic cell cultures. Interference between GR and AP-1 appeared to be cell specific as previously reported, in particular for NIH-3T3 cells (Maroder et al. 1993).

\section{Regulation of TRH release and content in hypothalamic cultures}

Rapid effects of glucocorticoids can occur at the membrane level affecting intracellular calcium or protein kinases that can alter, for example, vasopressin release (Makara \& Haller 2001, Chen \& Qiu 1999). We studied if the release of TRH was regulated in hypothalamic cells treated for 1-2 h with dex or 8Br-cAMP, alone or combined. Increased release was detected after $1 \mathrm{~h}$ incubation with $8 \mathrm{Br}-\mathrm{cAMP}$ and was still evident at $2 \mathrm{~h}$ but TRH cell content was augmented only after $2 \mathrm{~h}$ incubation (Fig. 4). 8Br-cAMP produced a higher response than dex in TRH release and content, coincident with the faster and higher increase in proTRH mRNA levels (Uribe et al. 1995a, Perez-Martinez et al. 1998). Longer times were not studied since it would be difficult to discern a higher basal release due to higher peptide cell content, from a direct effect on regulated exocytosis (Luo et al. 1995, Nillni et al. 2000). TRH content was increased by 8Br-cAMP and dex but not with combined treatment (Fig. 4B), as pre- viously shown for proTRH mRNA levels (PérezMartínez et al. 1998). These results indicate a role for cAMP in modifying TRH release, besides its effect on biosynthesis. Changes in cell content reflected the effects found at transcription level: dex increased TRH cell content at $2 \mathrm{~h}$ and impeded the stimulatory effect of 8Br-cAMP. The lack of decreased content supported the assumption that, at the concentrations used, no cytotoxicity occurred.

\section{NA mimicked cAMP effects}

Fast modulation of TRH gene expression in the PVN has been observed in vivo when rats were exposed to cold ambient temperature (Uribe et al. 1993, Sánchez et al. 2001), a condition in which NA is a neurotransmitter candidate in the afferent pathway (Arancibia et al. 1989, Lechan \& Toni 1992). Since PKA activation is one of the main intracellular pathways activated by catecholamines, we tested the effect of NA on TRH content and release, and proTRH mRNA levels in hypothalamic cell cultures. A 1-h incubation with $10 \mathrm{nM}$ NA increased TRH release without affecting cell content (Fig. 5A). A fast and transient increase in proTRH mRNA levels was observed from $30 \mathrm{~min}$, was highest at $60 \mathrm{~min}$ and decreased after $120 \mathrm{~min}$ incubation with $10 \mathrm{nM}$ NA (Fig. $5 \mathrm{~B})$. NA at 1 or $100 \mathrm{nM}$ increased proTRH mRNA levels to $180 \pm 15$ or $191 \pm 17 \%$ respectively (controls $=100 \pm 5 \% ; \mathrm{n}=6, P<0 \cdot 01)$ after $1 \mathrm{~h}$ incubation. Pretreatment with H89 abrogated the stimulatory effect of NA while staurosporine did not (Fig. 5C). As observed for a cAMP analog (Pérez-Martínez et al. 1998), the NA-induced increase in proTRH mRNA levels was higher than that caused by dex and co-incubation of NA with dex diminished the response to NA (Fig. 5D and E). These results show that NA, a known physiological modulator, regulated TRH expression in a similar way to that observed with $8 \mathrm{Br}$-cAMP in primary cultures of fetal hypothalamus.

\section{Binding of nuclear extracts from hypothalamic cells to DNA sequences containing CRE and GRE sites}

\section{Binding to CRE}

To study if the interference of CREB with GR or AP-1 elements was due to their binding to DNA cognate sequences, we first analyzed if the proposed elements in the TRH promoter, involved in GREB or GR recognition, would bind nuclear proteins extracted from cells of fetal primary hypothalamic cultures incubated with dex or drugs that activate PKA or PKC. Cultures were treated at 14 DIV since at this time they have maximal TRH mRNA levels (Pérez-Martínez et al. 2001). Putative DNA binding sites for GREB, GR, and AP-1 in the rTRH promoter region are shown in 

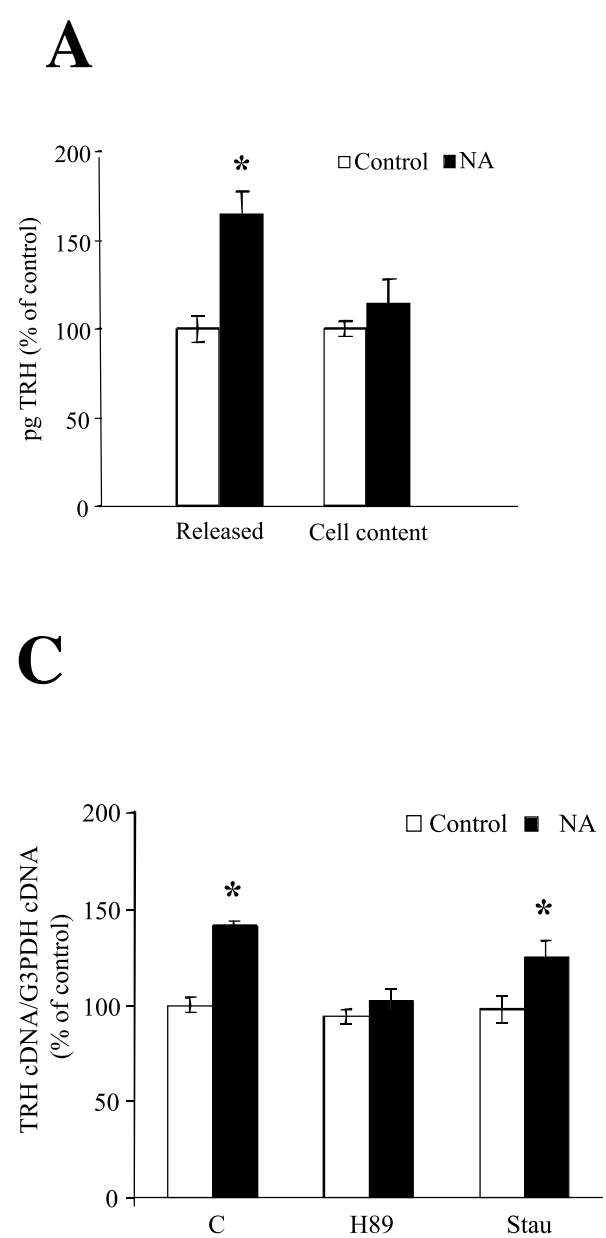

B

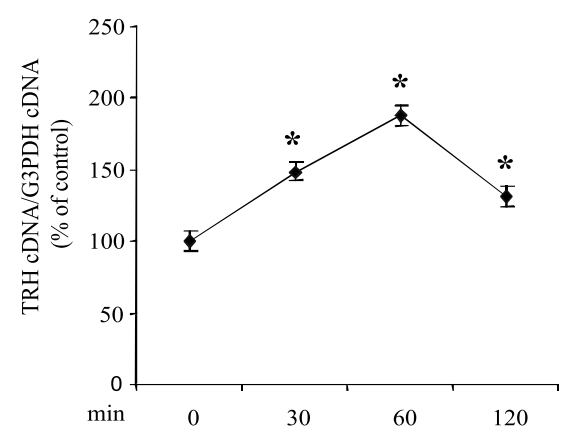

D

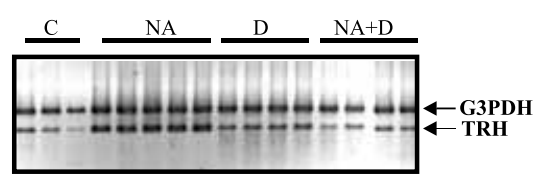

$\mathbf{E}$

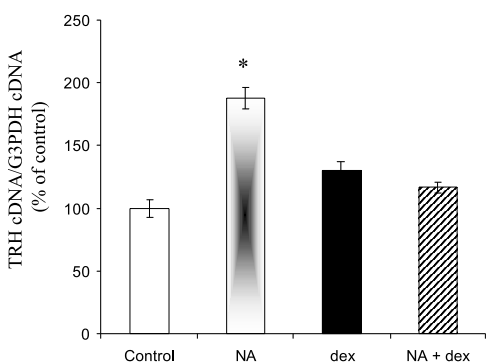

Figure 5 Effect of NA on TRH metabolism. (A) Hypothalamic cells (14 DIV) were incubated with, or without, $10 \mathrm{nM}$ NA (and $10 \mu \mathrm{M}$ ascorbic acid, present also in controls) for $1 \mathrm{~h}$ and $\mathrm{TRH}$ measured in the medium or cell content (as in Fig. 4); data are expressed as a percentage of control $(n=6)$, ${ }^{\star} P<0 \cdot 01$. (B) Cells were incubated with $10 \mathrm{nM}$ NA for 30,60 or $120 \mathrm{~min}$; they were rinsed, total RNA extracted, and proTRH mRNA levels measured by semi-quantitative RT-PCR. Values are expressed as a percentage of controls $(n=8),{ }^{*} P<0.01$. (C) Cells were preincubated for 30 min with H89 (50 nM) followed by $1 \mathrm{~h}$ with $10 \mathrm{nM}$ NA or $10 \mathrm{nM}$ staurosporine (Stau); proTRH mRNA levels were measured as in panel $\mathrm{B}(n=6),{ }^{*} P<0.05$. (D) Representative gel of RT-PCR products (of samples from panel E). (E) Cells were treated for $1 \mathrm{~h}$ with $10 \mathrm{nM} N A$ or $1 \mathrm{nM}$ dex, alone or combined; proTRH mRNA levels were measured as in panel $\mathrm{B}(n=15),{ }^{\star} P<0.01$ vs control.

Fig. 1. Two sites have been described as possible CREs: CRE-2 at $-101 /-94$ and CRE- 1 at $-59 /-52$; as mentioned, CRE-1 (site 4) has received exclusive attention as a target for CREB, AP-1 and TR. Since CREB phosphorylation increases DNA binding in canonical sequences and particularly in non-canonical sites (Benbrook \& Jones 1994, Bullock \& Habener 1998), we analyzed by EMSA whether nuclear extracts from hypothalamic cells treated with 8Br-cAMP had enhanced DNA-binding activity to the putative CRE elements located on the TRH promoter. Using CRE-1, two faint bands were observed with nuclear extracts from hypothalamic cells; they did not differ in intensity if the nuclear extracts were obtained from cells incubated (1-3 h) with 8Br-cAMP, TPA or dex (representative gel of some groups, in Fig. 7A).

To avoid the possibility of unidentified transcription factors binding to sequences adjacent to CRE elements (Dan et al. 1999), the formation of DNA-protein complexes was studied with an oligonucleotide comprising the regions including CRE-2 and CRE-1 (CRE-L) (Fig. 1). Increased binding was observed with CRE-L and nuclear extracts from hypothalamic cells incubated for $1-3 \mathrm{~h}$ with $8 \mathrm{Br}$-cAMP (Fig. 6A). Binding was prevented if cells were preincubated for $30 \mathrm{~min}$ with H89 while preincubation with H85 (inactive form of 


\section{Binding to CRE-L}

A
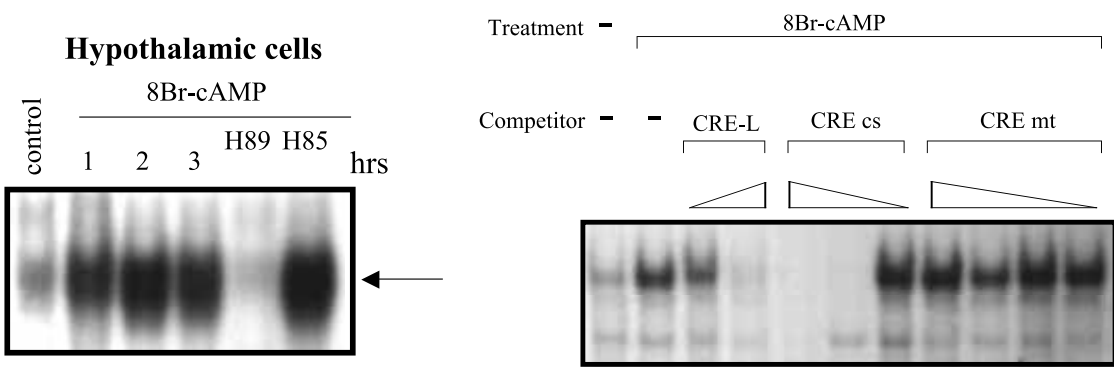

C

NIH-3T3 cells

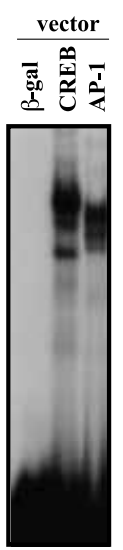

D

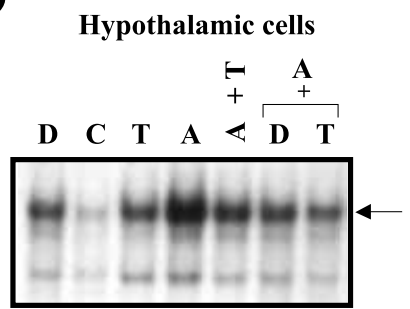

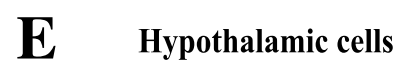

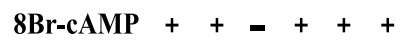

Antibody $\operatorname{IgG}$ - - P-CREB

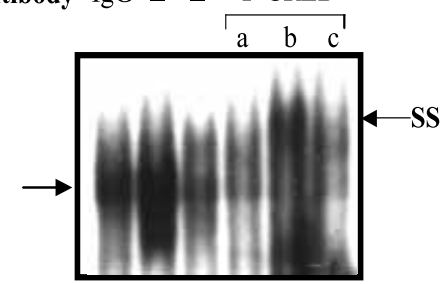

Figure 6 Binding activity to CRE-L induced by 8Br-cAMP involved CREB protein. (A) Nuclear extracts from hypothalamic cells (14 DIV) treated with $1 \mathrm{mM} 8 \mathrm{Br}$-cAMP for $1-3 \mathrm{~h}$ were incubated with ${ }^{32} \mathrm{P}$-labeled CRE-L (see Fig. 1). Some cells were preincubated with $\mathrm{H} 89$ or $\mathrm{H} 85$ for 30 min followed by $3 \mathrm{~h}$ with 8Br-cAMP. (B) As in panel A; DNA competition experiments were performed with: 10- or 100-fold of non-radioactive CRE-L; 100-, 10- or 1-fold of consensus CRE (cs); and mutated CRE (mt) (for sequences see Materials and methods). (C) AP-1 and CREB are able to bind independently to CRE-L. NIH-3T3 cells were transfected with either expression vector for $\beta$-galactosidase ( $\beta$-gal), CREB, or c-Fos and c-Jun; $48 \mathrm{~h}$ after transfection nuclear extracts were prepared and tested by EMSA using the CRE-L element. Arrows indicate the position of the major DNA-protein complexes. (D) TPA and dex signaling pathways reduce $8 \mathrm{Br}$-cAMP-induced binding to CRE-L. Nuclear extracts from 14-DIV hypothalamic cells treated for $3 \mathrm{~h}$ with: T, TPA; $\mathrm{A}, 8 \mathrm{Br}$-cAMP; or D, dex; alone or combined; C, unstimulated cells. Data shown are representative of at least three independent experiments. (E) Protein-CRE-L complexes induced by 8Br-cAMP contain phospho-CREB. Nuclear extracts from $8 \mathrm{Br}$-cAMP-treated hypothalamic cultures $(3 \mathrm{~h})$ were incubated with anti P-CREB before (a) or after (b, $1 \mu \mathrm{g} ; \mathrm{c}, 0.5 \mu \mathrm{g})$ adding CRE-L, or with an irrelevant antibody (IgG) added after nuclear extracts were incubated with CRE-L. SS, the supershifted complex.

H89; Oki et al. 2000) had no effect (Fig. 6A), coincident with various reports that, in particular for non-canonical consensus sequences, phosphorylation induced by PKA stimulation increases binding to CRE (Bullock \& Habener 1998). Binding to CRE-L was abolished by competing with a $100 \times$ molar excess of cold CRE-L or consensus CRE; $100 \times$ molar excess of mutated CRE had no effect on binding to CRE-L (Fig. 6B). To determine if AP-1 and CREB were able to bind independently to CRE-L, NIH-3T3 cells were trans- fected with either CREB or c-Fos and c-Jun expression vectors; binding to CRE-L was observed with nuclear extracts from cells transfected with vectors for CREB, c-Fos and c-Jun while not with nuclear extracts from cells transfected with an expression vector for $\beta$-galactosidase (Fig. 6G). Primary cultures of hypothalamic cells were incubated for $3 \mathrm{~h}$ with dex, 8Br-cAMP or TPA, alone or combined, and their nuclei extracted to determine their ability to bind CRE-L. Binding was increased with nuclear extracts from dex- or 


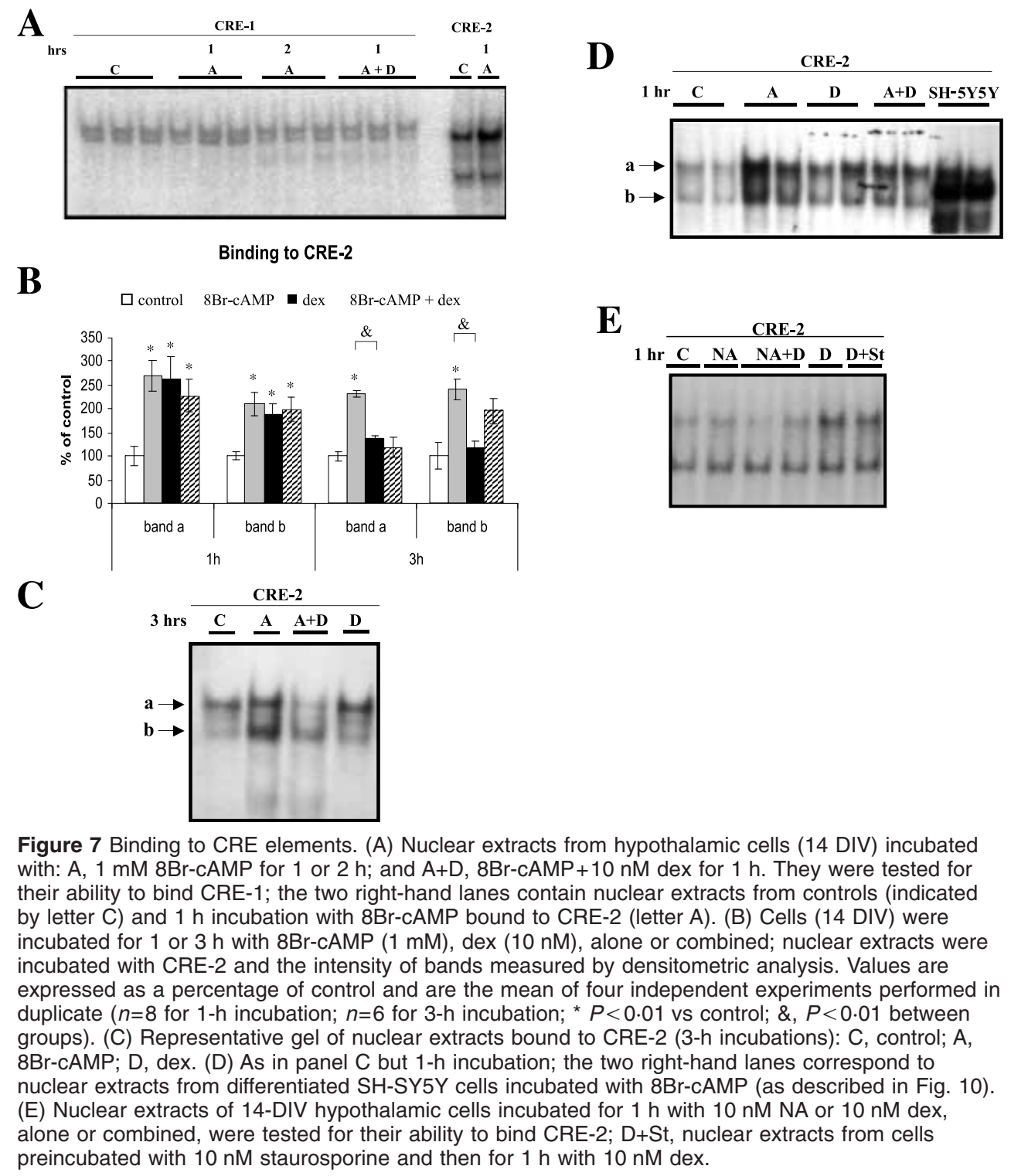

TPA-incubated cells (albeit in less magnitude to that seen with 8Br-cAMP) (Fig. 6D). Compared with the intensity observed with nuclear extracts from $8 \mathrm{Br}$ cAMP-stimulated cells, co-incubation of 8Br-cAMP with dex or TPA produced a less intense signal (Fig. 6D). Addition of P-CREB antibody to nuclear extracts from 8Br-cAMP-treated cells resulted in a supershifted complex (Fig. 6E), while the addition of an irrelevant antibody had no effect in the DNA-protein complex.

Thus, in hypothalamic cells, 8Br-cAMP induced P-CREB binding to an oligonucleotide containing both CRE-like elements, and binding to GRE-L was increased mainly with nuclear extracts from $8 \mathrm{Br}$-cAMP and, to a lesser extent, with nuclear extracts from TPA- or dex-treated cells. Combined treatments interfered with the $8 \mathrm{Br}$-cAMP signal. To verify if the second CRE site $-101 /-94$ was responsible for the increased binding, we used an oligonucleotide comprising the sequence - 106/-89 (CRE-2). Hypothalamic cells were incubated for $1-3 \mathrm{~h}$ with $8 \mathrm{Br}$-cAMP or dex, alone or combined. Densitometric analysis was performed in each gel and cultures were repeated at least three times with each condition in duplicate plates. Controls were taken as $100 \%$ for each culture and the mean of at least six values (two plates $\times$ three cultures) calculated. In contrast to the lack of increased binding to CRE-1 with nuclear extracts of 8Br-cAMP-incubated cells compared with non-treated cells, the same nuclear extracts showed 


\section{A Hypothalamic cells}

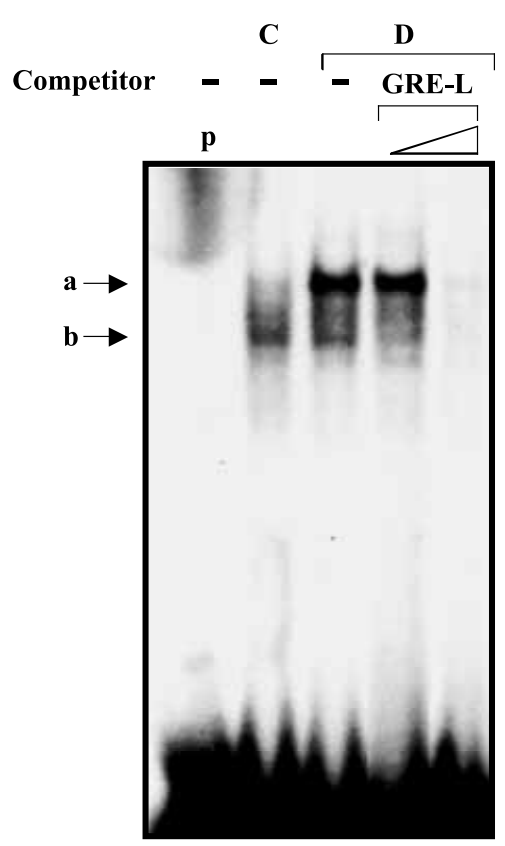

B

NIH-3T3 cells

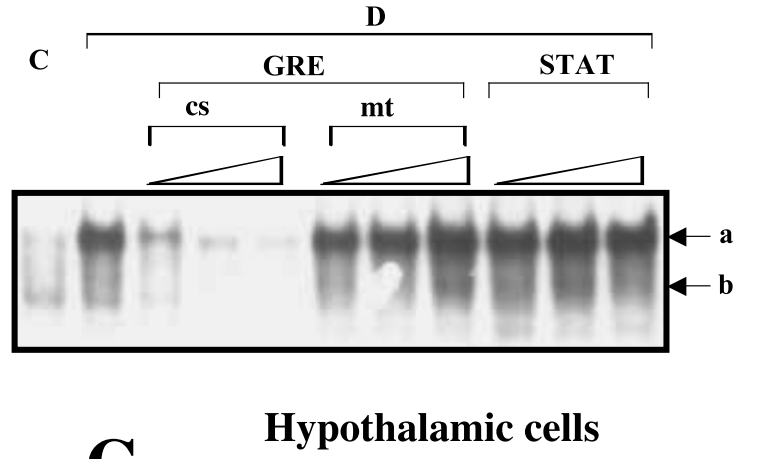

C

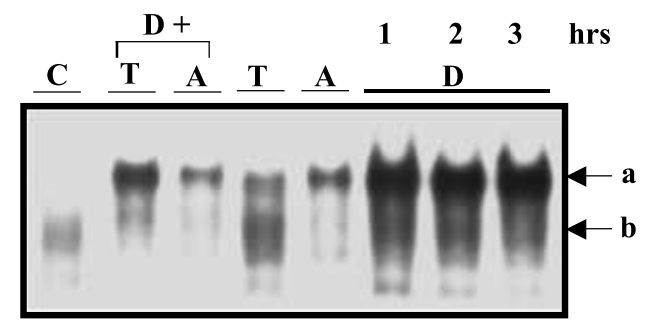

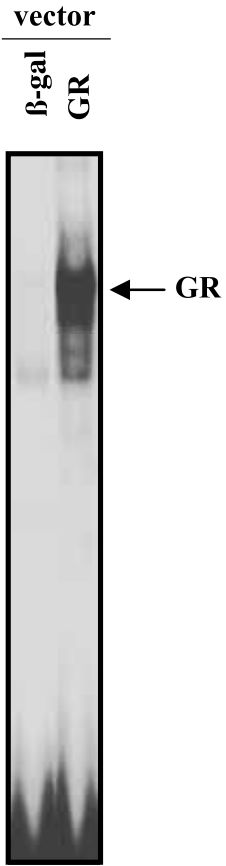

Figure 8 Binding to GRE-L in response to dex. (A) EMSA was performed using ${ }^{32}$ P-labeled double-stranded GRE-L (see Fig. 2) and nuclear extracts from 14-DIV hypothalamic cells: C, untreated; D, treated for $3 \mathrm{~h}$ with $10 \mathrm{nM}$ dex; $p$, probe with no nuclear extracts. DNA competition experiments were performed with 1-, 10- and 100-fold excess of non-radioactive GRE-L oligonucleotide: consensus GRE (cs), mutated GRE (mt) or STAT. (B) GR binds to GRE-L. NIH-3T3 cells were transfected with the expression vector for $\beta$-galactosidase ( $\beta$-gal) or GR; $48 \mathrm{~h}$ after transfection nuclear extracts were prepared and tested by EMSA using GRE-L. (C) Interference between $8 \mathrm{Br}$-cAMP and TPA signaling pathways with dex-induced binding to GRE-L. Hypothalamic cells (14 DIV) were treated with dex for $1-3 \mathrm{~h}(\mathrm{D})$ and TPA $(\mathrm{T})$ or $8 \mathrm{Br}$-cAMP $(\mathrm{A})\left( \pm\right.$ dex) for $3 \mathrm{~h}$. Nuclear extracts were incubated with ${ }^{32} \mathrm{P}-\mathrm{labeled}$ GRE-L and subjected to EMSA; $C$, extracts from unstimulated cells indicate the basal binding activity.

higher DNA binding activity with GRE-2 (Fig. 7A and C). Two distinctive bands were observed, both increased in nuclear extracts from 3-h incubates with 8Br-cAMP, and only the lower mobility band (band a) was increased in nuclear extracts of cells treated with dex; coincubation of dex $+8 \mathrm{Br}$-cAMP decreased intensity of band a (Fig. 7B and $\mathrm{C}$ ). Nuclear extracts from cells incubated for $1 \mathrm{~h}$ either with 8Br-cAMP or dex, alone or combined, showed band $\mathrm{b}$ more intense than that observed in nuclear extracts from 3-h incubates. Both bands showed similar increments upon treatment but the analysis of several cultures showed no significant difference between them (Fig. 7A and D). As observed for CRE-L, preincubation with H89 avoided the effect of $8 \mathrm{Br}$-cAMP (densitometric analysis of band a as a percentage of control $(100 \pm 12 \%)$ : 8Br-cAMP, $279 \pm$ $54 \% *$; H89+8Br-cAMP, $112 \pm 9 \%$; $* P<0 \cdot 01$ vs controls, $n=6)$. Nuclear extracts from cells incubated with NA for $1 \mathrm{~h}$ gave similar complexes to those observed with $8 \mathrm{Br}$-cAMP and co-incubation with dex diminished binding; the increased binding to GRE-2 by dex was not altered by preincubation with staurosporine (Fig. 7E).

\section{Binding to GRE}

As mentioned, the GRE half-site located at -210 / -205 confers dex response in transfected cells (Lee $e t$ al. 1996). However, adjacent to this site in the complementary strand are two sequences similar to the AP-1 response element (Fig. 1); this arrangement has been observed for corticotropin-releasing hormone $(\mathrm{CRH})$ and other genes, and is referred to as composite GRE (Miner \& Yamamoto 1992, Harrison et al. 1995, Malkoski \& Dorin 1999). We tested the ability of nuclear extracts from dex-treated hypothalamic cells $(3 \mathrm{~h})$ to bind to the oligonucleotide sequence $-220 /-193$ (GRE-L); two bands were observed with the upper one (lower mobility shown by letter a in Fig. 8A) increasing upon dex treatment (Fig. 8A). Competition assays with up to 100-fold excess of GRE-L or a consensus GRE completely abolished DNA binding while no competition was observed when the same amount of mutated GRE or STAT oligonucleotide was added (Fig. 8A). GR expressed in NIH-3T3 cells bound to GRE-L; no binding was detected with nuclear extracts 


\section{Binding to GRE-A \\ Hypothalamic cells}
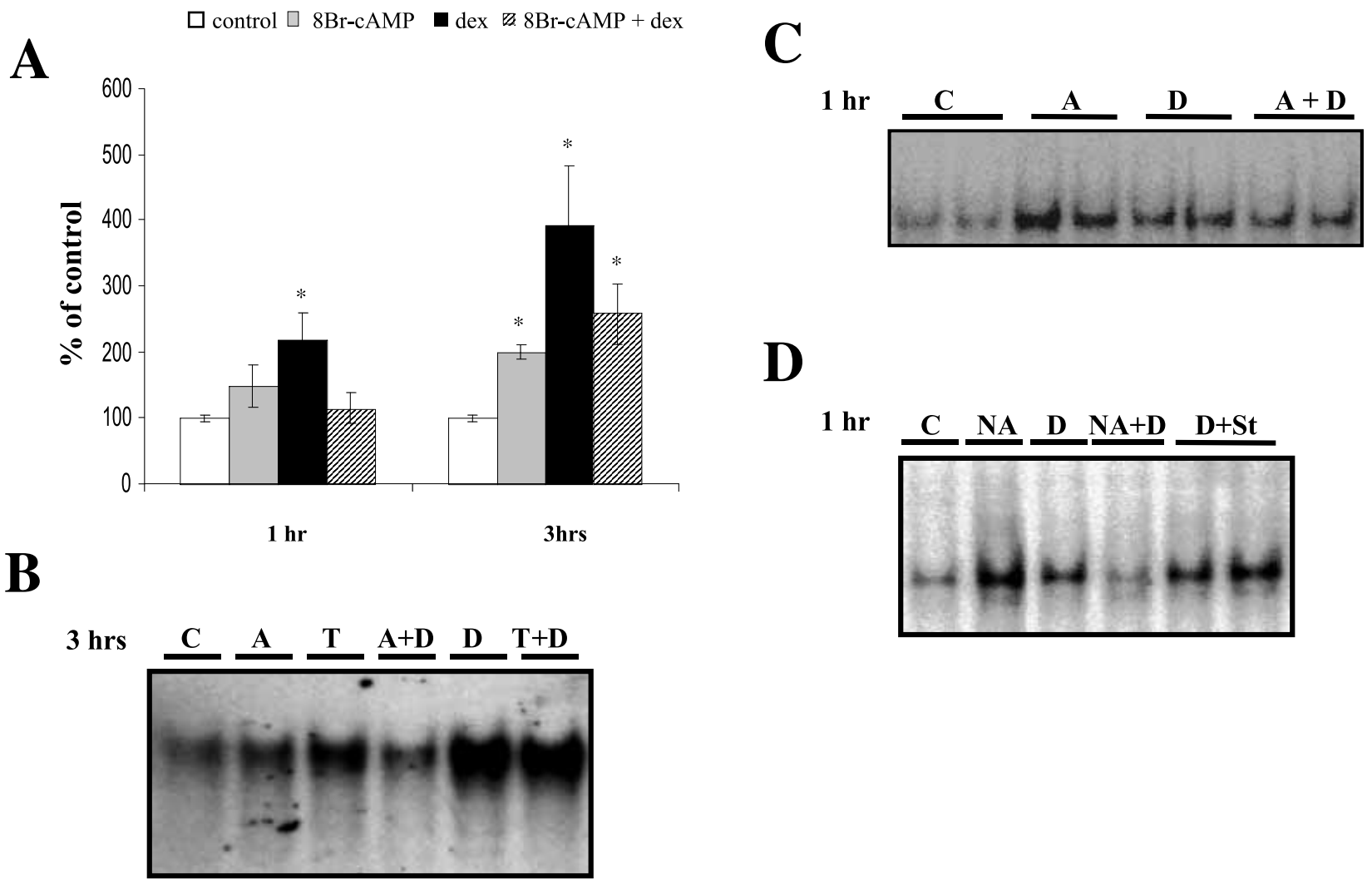

Figure 9 Binding to GRE-A. (A) Hypothalamic cells (14 DIV) were incubated for 1 or $3 \mathrm{~h}$ with $1 \mathrm{mM} 8 \mathrm{Br}-\mathrm{cAMP}$ and $10 \mathrm{nM}$ dex, alone or combined; nuclear extracts were incubated with GRE-A and the intensity of bands was measured by densitometric analysis. Values are expressed as a percentage of control and are the mean of four independent experiments performed in duplicate ( $n=8$ for 1 -h incubation; $n=6$ for 3 -h incubation; ${ }^{*} P<0.01$ vs controls). (B) Representative gel of nuclear extracts bound to GRE-A (3-h incubations): C, control; A, 8Br-cAMP; D, dex; T, TPA. (C) As in panel B but for a 1-h incubation. (D) Nuclear extracts of 14-DIV hypothalamic cells incubated for $1 \mathrm{~h}$ with $10 \mathrm{nM}$ NA and $10 \mathrm{nM}$ dex, alone or combined, were tested for their ability to bind GRE-A; D+St, nuclear extracts from cells preincubated with $10 \mathrm{nM}$ staurosporine and then for $1 \mathrm{~h}$ with $10 \mathrm{nM}$ dex.

from cells transfected with RSV- $\beta$-gal (Fig. 8B). Binding was increased with nuclear extracts from hypothalamic cells incubated with dex (1-3 h); TPA stimulation $(3 \mathrm{~h})$ increased the intensity of the faster mobility complex (indicated by letter b; Fig. 8C). Co-incubation of dex with 8Br-cAMP diminished binding compared with nuclear extracts from cells incubated only with dex; a slight decrease was observed in the signal of nuclear extracts from cells co-incubated with dex+TPA (Fig. 8G).

To further characterize the TRH composite GRE (cGRE), another oligonucleotide for GRE was synthesized excluding the first four bases of GRE-L to avoid the second AP-1-like sequence; this shorter oligonucleotide was named GRE-A (Fig. 1). Binding to GRE-A was studied in the same nuclear extracts used for CRE-2. Only one band was observed with GRE-A whether cells were incubated for 1 or $3 \mathrm{~h}$ with the drugs and the highest increase was upon dex treatment (Fig. 9); this band had a slower mobility than band $b$ of gels with GRE-2 (not shown). Highest binding was observed with nuclear extracts of cells treated for $3 \mathrm{~h}$ with dex (alone or combined with TPA) followed by the signal of 8Br-cAMP-treated cells (Fig. 9A and B); co-incubation with dex and 8Br-cAMP diminished the signal observed after dex treatment. Nuclear extracts from cells stimulated with dex for $1 \mathrm{~h}$ also showed increased binding to GRE-A which was avoided when cells were co-incubated with 8Br-cAMP (Fig. 9A and C). The PKA inhibitor H89 diminished (although not statistically significantly) the effect of dex on GRE-A binding (controls, $100 \pm 17 \%$; dex, $321 \pm 67 \%$ *; 


\section{SH-SY5Y cells}

A

$\square$ control $\square$ 8Br-cAMP $\square \operatorname{dex} \square$ 8Br-cAMP + dex

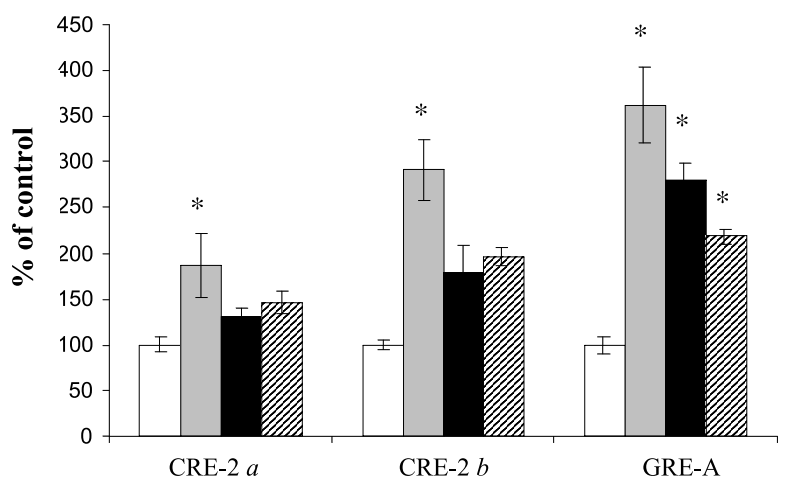

C

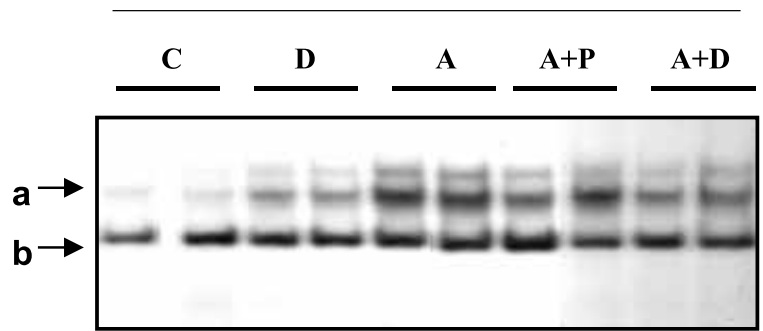

B

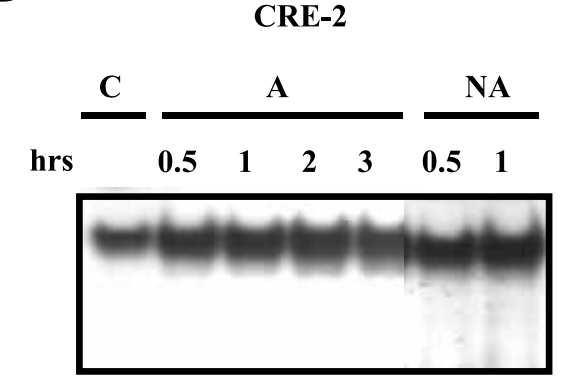

D

GRE-A

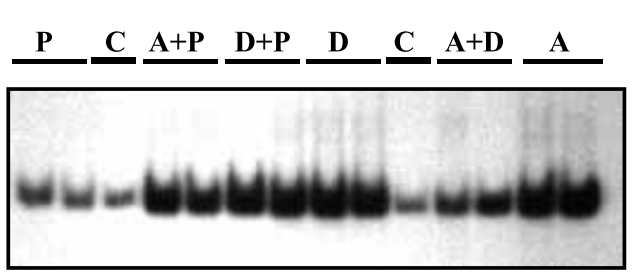

Figure 10 Binding of nuclear extracts of SH-SY5Y cells to CRE-2 and GRE-A. (A) SH-SY5Y cells (TPA-differentiated for 8 days) were incubated for $1 \mathrm{~h}$ with $1 \mathrm{mM} 8 \mathrm{Br}$-cAMP and $10 \mathrm{nM}$ dex, alone or combined; nuclear extracts were incubated with CRE-2 and GRE-A and the intensity of bands measured by densitometric analysis. Values are expressed as a percentage of control and are the mean of seven independent experiments performed in duplicate; ${ }^{*} P<0.01$ vs control. (B) CRE-2 bound with nuclear extracts from undifferentiated cells incubated with: A, $1 \mathrm{mM}$ 8Br-cAMP for $0.5-3 \mathrm{~h}$; or $10 \mathrm{nM}$ NA for $0.5-1 \mathrm{~h}$. (C) Representative gel of protein complexes bound to CRE-2 with nuclear extracts of differentiated cells treated with: A, $1 \mathrm{mM} 8 \mathrm{Br}-\mathrm{cAMP}$; D, $10 \mathrm{nM}$ dex; or $\mathrm{P}, 10 \mathrm{nM}$ progesterone. (D) GRE-A bound to nuclear extracts as described in panel C.

H89+dex, $197 \pm 73 \% ; * P<0 \cdot 01, n=4)$. Nuclear extracts from NA-stimulated cells increased binding to GRE-A which was strongly diminished when cells were co-incubated with NA and dex; staurosporine pretreatment had no effect on the increased binding due to dex (Fig. 9D).

The increased binding of nuclear extracts treated with TPA or 8Br-cAMP with GRE-L or GRE-A, compared with controls, supports this region as a composite GRE

\section{Neuroblastoma SH-SY5Y cells}

Primary cultures of hypothalamic cells constitute a heterogeneous population of neurons and glia from different hypothalamic nuclei expressing several neuromodulators. EMSA results are therefore due to the mean response of these cells. A neuronal cell line was used to determine if events identified in the mixed background are likely to operate in a neuronal population; also, to verify if the interferences observed are due to transcription factors, exclusive of hypothalamic cells. We studied the binding of nuclear proteins extracted from neuroblastoma SH-SY5Y cells since they respond to adrenergic signals, kinases activation and glucocorticoids (Tank \& Weiner 1992, Watters et al. 1997, Glick et al. 2000). Comparison was made between undifferentiated and differentiated cells. Nuclear extracts from undifferentiated cells treated with $8 \mathrm{Br}$-cAMP or dex showed increased binding to CRE-2 and GRE-A but to a lesser extent than that observed from differentiated cells (not shown). We therefore used differentiated cells and results are summarized in Fig. 10A. As with hypothalamic cells, a faint band was detected with CRE-1 that did not differ between cell treatments (not shown). Increased binding to CRE-2 was observed after $30 \mathrm{~min}$ with nuclear extracts from cells incubated with $8 \mathrm{Br}$-cAMP or NA 
A

Hypothalamic cells

CRE-2

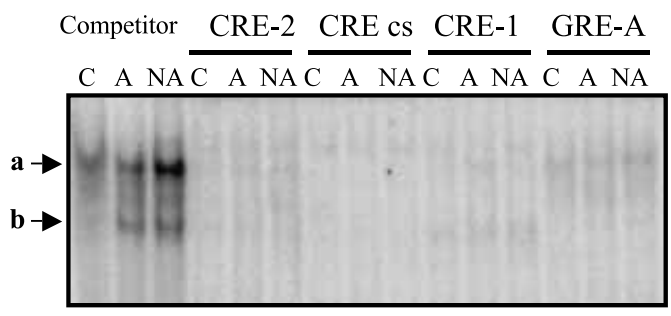

B

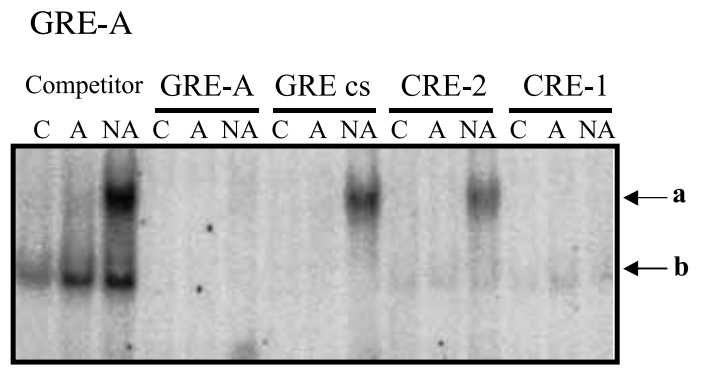

C

SH-SY5Y cells

CRE-2

Competitor CRE-2 CRE mt CRE-1

C A D AD C A D AD C A D AD C A D AD
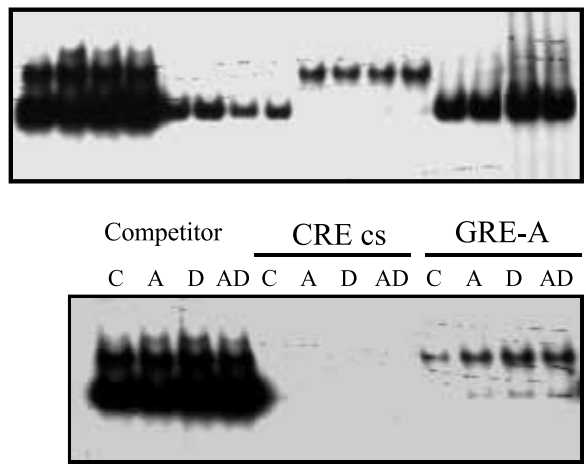

$\mathrm{D}$

GRE-A

Competitor GRE-A GRE cs CRE-2 CRE-1

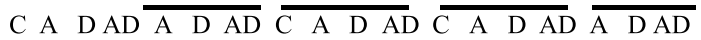

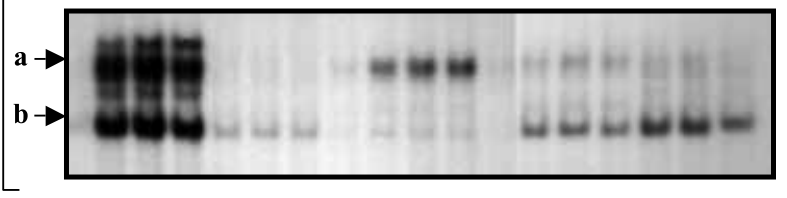

Figure 11 Competition for binding to short oligonucleotides. Nuclear extracts from 14-DIV hypothalamic cells treated for $1 \mathrm{~h}$ with $1 \mathrm{mM} 8 \mathrm{Br}-\mathrm{cAMP}$ or $10 \mathrm{nM}$ NA were tested for binding to CRE-2 (A) or GRE-A (B). (A) Nuclear extracts preincubated without competitor or with 100 ng CRE-2, consensus CRE (CRE cs), CRE-1 or GRE-A, and then with labeled CRE-2. (B) Nuclear extracts preincubated with 100-fold cold GRE-A, consensus GRE (GRE cs), CRE-2 or CRE-1, and then incubated with labeled GRE-A. (C) Nuclear extracts from differentiated SH-SY5Y cells treated with $1 \mathrm{mM} 8 \mathrm{Br}$-cAMP (A), $10 \mathrm{nM}$ dex (D), alone or combined (AD), were preincubated with 100-fold of either CRE-2, mutated CRE (CRE mt), CRE-1, CRE cS or GRE-A and then incubated with labeled CRE-2. (D) As in panel C, but incubated with labeled GRE-A and with GRE-A, consensus GRE, CRE-2 or CRE-1 as competitors.

(Fig. 10B). If gels ran for longer times, two bands were detected using CRE-2, with band b being stronger (Fig. 10C; the mobility of this band differed from that observed in nuclear extracts of hypothalamic cells, see Fig. 7D). Band b could correspond to AP-1 induced by TPA used for differentiation. The intensity of both bands was increased in nuclear extracts from 8Br-cAMPtreated cells and only slightly with dex-treated cells; co-incubation of dex +8Br-cAMP however, diminished the intensity of band a compared with that observed with 8Br-cAMP alone (Fig. 10C).

Binding to GRE-A was increased upon 8Br-cAMP incubation even further than with dex incubation; co-incubation considerably diminished the binding compared with that observed with $8 \mathrm{Br}$-cAMP alone and also, to a lesser but still significant extent, compared with dex-treated cells (Fig. 10A and D). The GRE half-site is also recognized by progesterone receptors (PRs) (Tank \& Weiner 1992) and, upon PKA activation, PR can bind to DNA without bound ligand (Lieberman et al. 1993, Cenni \& Picard 1999). Incubation of differentiated
SH-SY5Y cells with progesterone caused increased binding to GRE-A (Fig. 10D) in contrast to a very light band observed with hypothalamic cells (not shown). No interference either to GRE-A or CRE-2 binding was observed if progesterone was co-incubated with 8Br-cAMP (Fig. 10C and D).

\section{Competition and supershift analysis}

Binding to GRE-2 with nuclear extracts from hypothalamic cells treated with $8 \mathrm{Br}-\mathrm{cAMP}$ or NA was abolished with an excess of CRE-2 or consensus CRE; even though no increased binding to GRE-1 had been detected, this oligonucleotide was also able to displace binding of both complexes. GRE-A, which contains the perfect AP-1, displaced both bands but to a lesser extent, band a (Fig. 11A). The same extracts tested against GRE-A, with consensus GRE, GRE-A, CRE-2 and CRE-1 as competitors, showed complete displacement of band b. Mutual displacement of GRE-2 for GRE-A binding, and vice versa, suggests recognition of the AP-1 
site present in GRE-A by some of the protein complexes bound to CRE-2 (Habener 1990, Rutberg et al. 1999). One band of lower mobility (band a) was observed with nuclear extracts from NA-treated cells and GRE-A; the band was displaced with GRE-A and CRE-1 but only slightly with GRE-2 or consensus GRE (Fig. 11B).

Displacement of CRE-2 binding to nuclear extracts from SH-SY5Y-differentiated cells incubated with $8 \mathrm{Br}-\mathrm{cAMP}$ or dex was assayed. Gels were run for $3 \mathrm{~h}$ to separate the complexes efficiently. Only band a was displaced with cold CRE-1 or CRE-2 and slightly with GRE-A; in contrast, band b was preferentially displaced by GRE-A. Consensus CRE caused complete displacement of both bands (Fig. 11C). Binding to GRE-A was analyzed in gels run for $3 \mathrm{~h}$. Band a was displaced by GRE-A, CRE-2 and CRE-1 but not consensus GRE, while band $\mathrm{b}$ was displaced by either consensus GRE or GRE-A and only partially by CRE-2 (Fig. 11D). These results suggest that both bands were formed by different protein complexes.

In an attempt to characterize the nature of the proteins binding to CRE-2 or GRE-A we performed supershift analyses using antibodies recognizing P-CREB, c-Jun or GR. We were unable to detect a shifted band whether the antibody was incubated before or after DNA-protein complex formation; this could be due to instability of protein complexes with the antibody due to the short length of the oligonucleotides used (16 bp). However, binding to CRE-2 with nuclear extracts from hypothalamic 8Br-cAMP-treated cells diminished with P-CREB antibody $(46 \%$ vs $100 \%$ (signal in stimulated cells)) and with c-Jun antibody $(52 \%)$; this also occurred in dex-treated cells but to a lesser magnitude (74\%) (Fig. 12A). In contrast, binding to GRE-A with nuclear extracts from 8Br-cAMP-treated cells decreased only with c-Jun antibody (24\%), while from dex-treated cells binding decreased with c-Jun and GR antibodies (54\%) (Fig. 12B). The last lane of both gels corresponds to an equivalent amount of normal rabbit serum (NRS) and shows no decreased signal.

These results thus suggest that AP-1 and GR can bind to GRE-A and, also, to GR-c-Jun heterodimers (Miner \& Yamamoto 1992, Maroder et al. 1993).

\section{Discussion}

The homeostatic control of the thyroid axis requires adjustment to long-term changes occurring in conditions that cause metabolic alterations, such as during fasting (Blake et al. 1991, Legradi et al. 1997a). However, a rapid response to environmental stimuli is also a characteristic of the neuroendocrine systems. We have shown that the rapid increase in TRH mRNA levels observed after cold exposure or suckling stimulation - and mimicked in primary cultures of fetal hypothalamic cells incubated
A

\section{Hypothalamic cells}

CRE-2

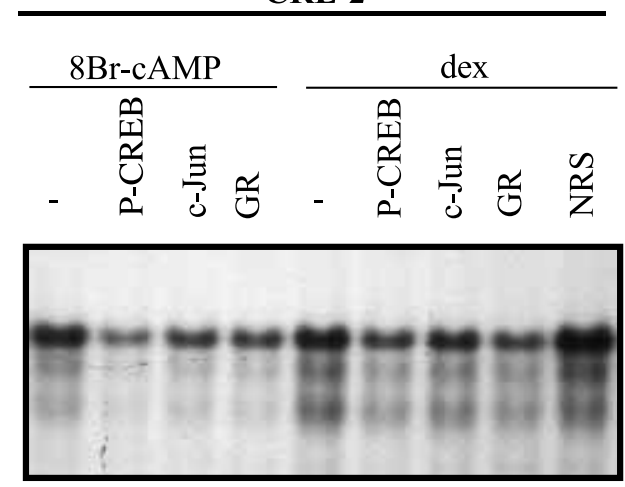

B

GRE-A

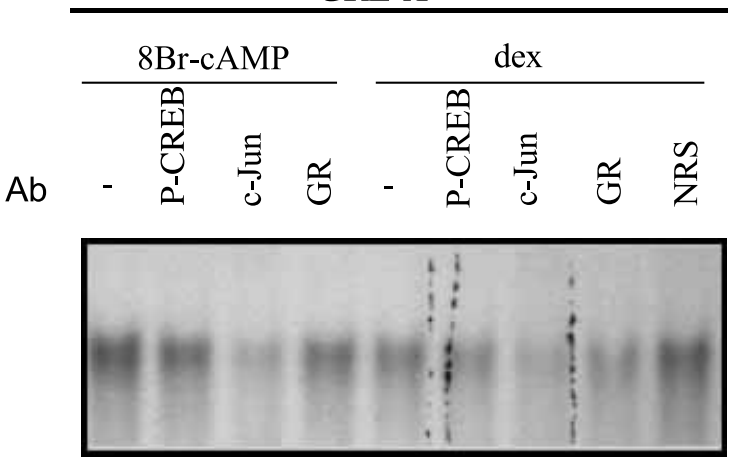

Figure 12 Supershift analysis. Hypothalamic cells (14 DIV) were incubated for $1 \mathrm{~h}$ with $1 \mathrm{mM} 8 \mathrm{Br}$-cAMP or $10 \mathrm{nM}$ dex; nuclear extracts were extracted and incubated for $10 \mathrm{~h}$ at $4{ }^{\circ} \mathrm{C}$ with $1 \mathrm{\mu g}$ of antibody against P-CREB, C-Jun or GR, or an equivalent amount of normal rabbit serum (NRS). ${ }^{32}$ P-labeled CRE-2 or GRE-A was added to the mixture for $30 \mathrm{~min}$. Electrophoresis ran for $8 \mathrm{~h}$ at $100 \mathrm{~V}$.

with PKA activators - could be due, at least in part, to regulation of transcription, as is the case for the interference caused by glucocorticoids on PKA signaling. Regulation of transcription can occur at different levels: at the binding of transcription factors; interactions between these factors affecting their binding to DNA; by appropriate recruitment of co-activators or corepressors, etc. (McKeena et al. 1999). We studied the possibility that the transcriptional interference observed between dex and 8Br-cAMP in neuronal cells could be at binding on their cognate sequences. The CRE-like sequence that recognized $8 \mathrm{Br}$-cAMP-activated nuclear proteins was the one located at $-101 /-94$. The GRE $-219 /-197$, corresponding to a composite GRE with AP-1 response elements flanking in the opposite strand, responded to dex and cAMP stimulation. Interference on binding was more strongly observed with the GRE. 
The hypothalamic cell culture optimized in our laboratory (Charli et al. 1995, Pérez-Martínez et al. 2001, Joseph-Bravo et al. 2002) has proven to respond not only to $8 \mathrm{Br}$-cAMP but also to NA stimulation by causing an increase in variables that act as indicators for the activation of TRH neurons: increase in peptide release, and its mRNA (Joseph-Bravo et al. 1998).

Release of glucocorticoids occurs in almost any stressful condition and even in events such as suckling (Herman et al. 1992, Uribe et al. 1993, Sánchez et al. 2001). The rise is immediate and therefore it is difficult to envisage situations that are free of variations in the levels of this hormone. How these variations modulate further responses is currently being investigated by many research groups. Positive or negative effects of glucocorticoids depend on the gene and the cellular make-up; their actions are not exclusive to an interaction with the mineralocorticoid or glucocorticoid receptors (with or without DNA binding) but also affect the transcriptional activity of other factors (Newton 2000, de Bosscher et al. 2001, Schaaf \& Cidlowski 2003). It is now recognized that glucocorticoids can act at the membrane level activating second messenger pathways and release of various neuromodulators and hormones (Chen \& Qiu 1999). We found no effect of dex on TRH release after $1 \mathrm{~h}$ incubation but the possibility remains that some of its effects on proTRH mRNA levels were initiated at the plasma membrane. We have previously reported that dex-mediated upregulation of proTRH mRNA levels $(1 \mathrm{~h})$ occurs independently of protein synthesis (PérezMartínez et al. 1998). The stimulatory effect of PKA activation or glucocorticoids on proTRH mRNA levels in hypothalamic cell cultures can occur at the level of gene transcription since in transfected hypothalamic cells, 8Br-cAMP or dex increased luciferase activity under the control of TRH promoter. The degree of transcriptional activation varied between these pathways depending on the cell system. Compared with the extent of stimulation obtained by PKA activation or dex treatment in primary cultures on proTRH mRNA levels (4-5-fold by $8 \mathrm{Br}$-cAMP vs 3 -fold by dex (Pérez-Martínez et al. 1998)), 8Br-cAMP-induced luciferase activity was higher than that induced by AP-1 or GR, despite the fact that there were no major differences in the expression levels of the transcription factors as determined by DNA-binding activity (transfected homologous system: primary hypothalamic cell cultures, 7vs 2-fold for $8 \mathrm{Br}$-cAMP vs dex stimulation respectively; heterologous system: $32-$ vs $2 \cdot 7$-fold respectively). This discrepancy could be explained by the difference in GR activity on a stably integrated template (and its effect on chromatin remodeling and recruitment of coactivators) compared with a naked transiently transfected promoter (McKeena et al. 1999).

The interference caused by dex (or GR) on 8Br-cAMP (or CREB) activation on proTRH mRNA levels also occurred at the transcriptional level as observed for CRH (Guardiola-Díaz et al. 1996, Malkoski et al. 1997, King et al. 2002), vasopressin (Kuwara et al. 2003) or the $\alpha$-subunit gene of glycoprotein hormone (Stauber et al. 1992); while in some of these cases dex alone can cause inhibition or no effect, TRH regulation coincides with that of annexin Al that is stimulated by dex or cAMP but when combined, inhibition is observed (Antonicelli et al. 2001).

Interaction between transcription factors occurs at different steps, some of which are independent of DNA binding, at least for one of them (Newton 2000, Schaaf \& Cidlowski 2003). We studied whether the inhibitory effect of dex on 8Br-cAMP activation was related to altered DNA binding to either GRE or GRE sites. Activation of the PKA-dependent signal pathway led to the binding of P-CREB to a synthetic oligonucleotide containing in tandem both putative TRH CRE non-canonical sequences. The specific nature of P-CREB binding to the TRH CRE-L element was demonstrated by competition studies, by supershift assays using an antibody specific for P-CREB, and binding of transfected CREB. TPA-mediated TRH promoter activity in cell cultures correlated with the induction of protein complexes binding to the TRH CRE; these complexes probably included AP-1 since over-expression of c-Jun and c-Fos in NIH-3T3 fibroblasts produced a complex able to bind CRE-L. P-CREB and AP-1 could thus bind to overlapping regulatory elements of the rat TRH promoter. When both CRE elements were independently studied with short oligonucleotides (16 bp), CRE-2 showed increased binding with nuclear extracts from 8Br-cAMP-treated cells but not CRE-1, which presented a very faint non-inducible band. These two elements differ from the consensus GRE (TGAGGTCA): CRE-2 (TGGGGTCA) and CRE-1 (TGACGTCA). Variations from the consensus sequence cause differences in binding affinity (Benbrook \& Jones 1994) and phosphorylation of CREB influences DNA-binding affinities on sequences deviating from the canonical symmetrical site, and also that of the consensus sequence (Bullock \& Habener 1998). CRE-1, within a longer oligonucleotide $(-83 /-36)$, is recognized by transfected CREB and only slightly by the endogenous form present in 293T cells (Harris et al. 2001). Although the sequence present in GRE-1 has a similar binding affinity to consensus CRE (Bullock \& Habener 1998), it remains to be studied whether the adjacent contextual sequences are required for CRE-1 to function properly in the TRH promoter (Deutch et al. 1988). The rat serine dehydratase gene possesses two CRE sites: a CRE-1 identical to TRH CRE-1, and another CRE-like sequence that has the conserved critical internal $\mathrm{CpG}$ dinucleotide (TGCGGCAA) supposed to have an important role in adequate binding (Deutch et al. 1988, Haas \& Pitot 1999); the second site was found to be the preferred binding site to CREB 
(Haas \& Pitot 1999). CRE-2 in the TRH promoter also contains this central CpG dinucleotide; whether this explains the difference in binding of hypothalamic nuclear extracts with CRE-2 vs CRE-1 will have to be confirmed by foot-printing and deletion analysis (in future studies). It cannot be overlooked, however, that when the CRE-1 site is mutated to TAAAACT, basal and $\alpha \mathrm{MSH}$-stimulated transcription of $-150 /+5$ hTRH transfected promoter is lost (Harris et al. 2001). This site is also the preferred binding site of TRs and cells transfected with $-177 /+83 \mathrm{TRH}$ promoter have increased transcriptional activity if cotransfected with TRs in the absence of $\mathrm{T}_{3}$, and repressed by addition of the hormone (Feng et al. 1994, Satoh et al. 1996, 1999). This site is close to the initiation site and the negative effect of $\mathrm{T}_{3}$ has been proposed to alter TR conformation such that it interferes, through protein-protein interactions, with basal transcriptional machinery (Feng et al. 1994, Satoh et al. 1996). Whether mutation of this site affects not only CREB binding, but also TR or other factors, remains to be studied. Furthermore, since these studies have been performed in non-neuronal cells, the possibility remains that in other cell types CREB-like proteins (or particular heterodimers) different from those of neurons are able to recognize CRE-1.

Two DNA-protein complexes are observed with CRE-2: band a is only displaced by CREs but not by GRE-A; in contrast, band b could contain AP-1-related factors, as judged by preferential displacement by GRE-A. When binding to CRE-2 with nuclear extracts from hypothalamic cells was compared with that of SH-SY5Y cells, band a coincided in both cultures while band $b$ differed from the most intense band, highly increased in TPA-differentiated cells. The nature of these complexes remains to be elucidated since GRE is recognized by several protein complexes with different affinities: various CREBs, CRE modulators (CREMs), AP-1, CREB-activating transcription factor-1 (ATF1), c-Jun homodimers and heterodimers with ATF2, to name a few (Habener 1990, Masquillier \& Sassone-Corsi 1992, Rutberg et al. 1999). Partial characterization of complexes by supershift assays suggests that CREB and Jun antibodies inhibit binding to CRE-2; the relative levels of these factors may thus influence transcriptional activity and affect the levels of proTRH mRNA without evident changes in the intensity of bound complexes. The increased binding to CRE-2 in nuclear extracts from hypothalamic cells stimulated after dex incubation for $1 \mathrm{~h}$ points to a membrane-mediated effect through kinase pathways; although this is partially supported by the small inhibitory effect of H89, staurosporine had no effect; other pathways remain to be studied.

Many of the effects of dex on gene expression are mediated by binding of the glucocorticoid receptor to its cognate DNA sequences on the target promoters (Newton 2000, Schaaf \& Cidlowski 2003). Our results show that dex stimulation of hypothalamic cells induced GR binding to a TRH GRE. This binding activity was competed with an oligonucleotide containing a consensus GRE and not by a mutated GRE; transfected GR bound to GRE-L with similar mobility. Since TPA stimulation produced a second band, this oligonucleotide was shortened to avoid the second AP-1 site. Dex-treated hypothalamic cells showed higher binding to GRE-A than cells treated with $8 \mathrm{Br}$-cAMP for 1 or $3 \mathrm{~h}$; in contrast, neuroblastoma cells presented an equivalent or higher binding after 8Br-cAMP than after dex stimulation. PKA activation increases GR binding to GRE (Rangarajan et al. 1992); however, the presence in GRE-A of AP-1 consensus sequences that recognize nuclear proteins activated by TPA stimulation and even by CREB (Deutch et al. 1988, Habener 1990, Masquillier \& Sassone-Corsi 1992, Hill \& Treisman 1995, Malkoski \& Dorin 1999, Rutberg et al. 1999) stresses the need for characterization of these complexes.

It has been recognized that there is no general competition model to explain interaction between transcription factors; effects depend on the cell type or the promoter, and can occur at different levels (Harrison et al. 1995, McKeena et al. 1999, Yamada et al. 1999, de Bosscher et al. 2001). A clear antagonism was observed between dex and 8Br-cAMP stimulation - whether in mRNA levels, transcription activity or, in certain conditions, DNA binding. Several forms of interaction have been proposed between PKA and glucocorticoids. Those related to DNA binding include: CREB-GR direct interactions avoiding DNA binding (Imai et al. 1993, Yamada et al. 1999) and sequestration of PKA signaling (Doucas et al. 2000). However, with these mechanisms, a mutual inhibition would be expected either on CRE or GRE sites but we observed an inhibition of protein binding to CRE only after $3 \mathrm{~h}$ incubation. The decreased binding to GRE (either CRE-L or CRE-2) could be due to glucocorticoids inhibiting CREB phosphorylation (Legradi et al. 1997b, Whitehead \& Carter 1997). In contrast, binding to the composite GRE (GRE-A) was diminished at 1 and $3 \mathrm{~h}$ in dex+8Br-cAMP hypothalamic 14 DIV cells and in differentiated neuroblastoma cells. Since GR half-life is diminished to $3 \mathrm{~h}$ after hormone binding but is increased by cAMP to $10 \mathrm{~h}$ (Dong et al. 1999), decreased binding to GRE-A cannot be explained by shortening GR halflife after 1-h stimulation. In the $\mathrm{CRH}$ promoter, a consensus GRE sequence and a composite GRE are involved in its transcriptional regulation; the stimulatory effect of PKA activation is mediated by CRE (Guardiola-Díaz et al. 1996) but cGRE participates in glucocorticoid-dependent repression of PKA-induced transcription (Malkoski et al. 1997, Malkoski \& Dorin 1999). Furthermore, the GRH gene can be induced by glucocorticoids in certain conditions through a different region in the promoter (King et al. 2002). The nature of 
the different nucleoproteins able to bind to a composite GRE determines the composition of coactivators or corepressors that ultimately define the positive or negative effects. In the case of the proTRH gene, a heterodimer GR-Jun (suggested to bind to composite GREs (Miner \& Yamamoto 1992, Maroder et al. 1993)) may be formed, and the response could depend on the type of complex bound (c-Jun homodimer, CREB, GR-Jun, etc). Differential effects of c-Jun forming particular dimers could affect CREB or GR binding, and/or their transcriptional activity; thus, a working hypothesis of c-Jun as a central regulator of proTRH expression seems worth considering.

In conclusion, the ensemble of these results demonstrates rapid regulation of TRH gene transcription by $8 \mathrm{Br}$-cAMP which can be repressed by dex in hypothalamic or in NIH-3T3 cells. In hypothalamic cells, NA reproduced the stimulatory effect of $8 \mathrm{Br}$-cAMP on proTRH mRNA levels and interacted similarly to 8Br-cAMP co-stimulation with dex, supporting a physiological relevance of this interaction. We identified a CRE site located at $-101 /-94$, and a composite GRE ( - 210/ - 205), that may regulate the transcriptional effects of various information pathways in neuronal cells. We have restricted the analysis to the role of PKA but other pathways activated by cAMP remain to be studied; additional work such as DNA foot-printing and deletion analysis, as well as further characterization of the protein complexes observed in EMSA studies, is thus warranted.

\section{Acknowledgements}

We thank Dr Gustavo Pedraza-Alva and Dr Gonzalo Aranda for helpful discussions and suggestions. The technical support of F Romero and M Villa, as well as the animal care of S González-Trujillo and E Mata is acknowledged. The authors thank E Bustos for the synthesis of the oligonucleotides used in this work as well as R Ciria and A Linares for cybernetic assistance. The authors declare that there is no conlfict of interest that would prejudice the impartiality of this scientific work.

\section{Funding}

This work was supported by grants from CONACYT (33351 and 35806N-Milenio) and DGAPA-UNAM (IX245204).

\section{References}

Abel ED, Rexford SA, Boers ME, Elmquist JK \& Wondisford FE 2001 Critical role for thyroid hormone receptor $\beta 2$ in the regulation of paraventricular thyrotropin-releasing hormone neurons. Fournal of Clinical Investigation 107 1017-1023.
Antonicelli F, Coupade C, Russo-Marie F \& Garrec Y 2001 CREB is involved in mouse annexin Al regulation by cAMP and glucocorticoids. European Fournal of Biochemistry 268 62-69.

Arancibia S, Tapia-Arancibia L, Assenmacher I \& Astier H 1983 Direct evidence of short-term cold-induced TRH release in the median eminence of unanesthetized rats. Neuroendocrinology 37 225-228.

Arancibia S, Tapia-Arancibia L, Astier H \& Assenmacher I 1989 Physiological evidence for $\alpha_{1}$-adrenergic facilitatory control of the cold-induced TRH release in the rat, obtained by push-pull cannulation of the median eminence. Neuroscience Letters $\mathbf{1 0 0}$ 169-174.

Balkan W, Tavianini MA, Gkonos PJ \& Roos BA 1998 Expression of rat thyrotropin-releasing hormone (TRH) gene in TRH-producing tissues of transgenic mice requires sequences located in exon 1. Endocrinology 139 252-259.

Benbrook DM \& Jones NC 1994 Different binding specificities and transactivation of variant CRE's by CREB complexes. Nucleic Acid Research 22 1463-1469.

Blake NG, Eckland DJ, Foster OJ \& Lightman SL 1991 Inhibition of hypothalamic thyrotropin-releasing hormone messenger ribonucleic acid during food deprivation. Endocrinology 129 $2714-2718$

Bradford MM 1976 A rapid and sensitive method for quantitation of microgram quantities of protein utilizing the principle of protein-dye binding. Analytical Biochemistry 72 248-254.

Bruhn TO, Bolduc TG, Rondeel JMM \& Jackson IMD 1994 Thyrotropin-releasing hormone gene expression in the anterior pituitary. II Stimulation by glucocorticoids. Endocrinology 143 821-825.

Bullock BP \& Habener JF 1998 Phosphorylation of the cAMP response element binding protein CREB by cAMP-dependent protein kinase A and glycogen synthase kinase-3 alters DNA-binding affinity, conformation and increase net charge. Biochemistry 37 3795-3809.

Cenni B \& Picard D 1999 Ligand-independent activation of steroid receptors: new roles for old players. Trends in Endocrinology and Metabolism 10 41-46.

Charli JL, Cruz C, Redondo JL, Guerra C \& Joseph-Bravo P 1995 Homologous conditioned medium enhances expression of TRH in hypothalamic neurons in primary culture. Developmental Brain Research 89 155-160.

Chen YZ \& Qiu J 1999 Pleiotropic signaling pathways in rapid, nongenomic action of glucocorticoid. Molecular Cell Biology Research Communications 2 145-149.

Covarrubias L, Uribe RM, Méndez M, Charli JL \& Joseph-Bravo P 1988 Neuronal TRH synthesis: developmental and circadian TRH mRNA levels. Biochemical and Biophysical Research Communications 151 615-622.

Dahlman-Wright K, Wright A, Gufstafsson JA \& Carlstedt-Duke J 1991 Interaction of the GT-DNA-binding domain with DNA as a dimer is mediated by a short segment of 5 amino acids. Fournal of Biological Chemistry 266 3107-3112.

Dan S, Tanimura A \& Yoshida M 1999 Interaction of Gli2 with CREB protein on DNA elements in the long terminal repeat of human T-cell leukemia virus type 1 is responsible for transcriptional activation by tax protein. Fournal of Virology $\mathbf{7 3}$ 3258-3263.

De Bosscher K, Berghe WV \& Haegeman G 2001 Glucocorticoid repression of AP-1 is not mediated by competition for nuclear coactivators. Molecular Endocrinology 15 219-227.

de Greef WJ, Voogt JL, Visser TJ, Lamberts SW \& van der Schoot P 1987 Control of prolactin release induced by suckling. Endocrinology 121 316-322.

Deutch PJ, Hoeffer JP, Jameson JL, Lin JC \& Habener JF 1988 Structural determinants for transcriptional activation by cAMP-responsive DNA elements. Fournal of Biological Chemistry 263 18466-18472. 
Dong Y, Aronsson M, Gustaffson JA \& Okret S 1999 The mechanism of cAMP-induced glucocorticoid receptor expression. Journal of Biological Chemistry 264 13679-13683.

Doucas V, Shi Y, Miyamoto S, West A, Verma I \& Evans RM 2000 Cytoplasmic catalytic subunit of protein kinase A mediates cross-repression by NF- $\mathrm{BB}$ and the glucocorticoid receptor. PNAS 97 11893-11898.

Fekete C, Sarkar S, Rand WM, Harney JW, Emerson CH, Bianco AC \& Lechan RM 2002 Agouti-related protein (AGRP) has a central inhibitory action on the hypothalamic-pituitary-thyroid (HPT) axis; comparison between the effect of AGRP and neuropeptide $\mathrm{Y}$ on energy homeostasis and HPT axis. Endocrinology 143 3846-3853.

Feng P, Li QL, Satoh T \& Wilber JF 1994 Ligand (T3) dependent and independent effects of TH receptors upon human TRH gene transcription in neuroblastoma cells. Biochemical and Biophysical Research Communications 200 171-177.

Fink G, Koch Y \& Ben-Aroya N 1993 TRH in hypophysial portal blood: characteristics of release and relationship to thyrotropin and prolactin secretion. In Thyrotropin-Releasing Hormone, pp 127-144. Eds EC Griffiths \& GW Bennett. New York: Raven Press.

Fragner P, Lee SL \& Aratan de Leon S 2001 Differential regulation of the TRH gene promoter by triiodothyronine and dexamethasone in pancreatic islets. Fournal of Endocrinology 170 91-98.

Glick RD, Medary I, Aronson DC, Scotto KW, Swendeman L \& La Quaglia MP 2000 The effect of serum depletion and dexamethasone on growth and differentiation of human neuroblastoma cell lines. Fournal of Pedriatic Surgery 35 465-472.

González GA, Yamamoto KK, Fischer WH, Karr D, Menzel P, Biggs W 3rd, Vale WW \& Montminy MR 1989 A cluster of phosphorylation sites on the cyclic AMP-regulated nuclear factor CREB predicted by its sequence. Nature 337 749-752.

Guardiola-Díaz HM, Kolinske JS, Gates LH \& Seasholtz AF 1996 Negative glucocorticoid regulation of cyclic adenosine $3^{\prime}, 5^{\prime}$-monophosphate-stimulated corticotropin-releasing hormone-reporter expression in AtT20 cells. Molecular Endocrinology $10317-329$.

Guerra-Crespo M, Charli JL, Rosales-Garcia VH, Pedraza-Alva G \& Pérez-Martínez L 2003 Polyethylenimine improves the transfection efficiency of primary cultures of post-mitotic rat fetal hypothalamic neurons. Fournal of Neuroscience Methods 127 179-192.

Guissouma H, Becker N, Seugnet I \& Demeneix A 2000 Transcriptional repression of TRH promoter function by T3: analysis by in vivo gene transfer. Biochemistry and Cell Biology 78 155-163.

Gynheung AN, Hidaka K \& Siminovitch L 1982 Expresssion of bacterial $\beta$-galactosidase in animal cells. Molecular and Cellular Biology 2 1628-1632.

Haas MJ \& Pitot HC 1999 Glucocorticoids stimulate CREB binding to a cyclic-AMP response element in the rat serine dehydratase gene. Archives of Biochemistry and Biophysics 362 317-324.

Habener JF 1990 Cyclic AMP response element binding proteins: a cornucopia of transcription factors. Molecular Endocrinology 4 $1087-1094$

Haisenleder DJ, Orotlano GA, Dalkin AC \& Marschall JC 1992 Differential actions of TRH pulses in the expression of prolactin and TSH subunit messenger ribonucleic acid in rat pituitary cells in vitro. Endocrinology $1302915-2923$.

Harris M, Aschkenasi C, Elias CF, Chandrankunnel A, Nillni EA, Bjorbaek C, Elmquist JK, Flier JS \& Hollenberg AN 2001 Transcriptional regulation of thyrotropin-releasing hormone by leptin and melanocortin signaling. Fournal of Clinical Investigation $107111-120$.

Harrison RJ, McNell GP \& Dobner PR 1995 Synergistic activation of neurotensin/neuromedin $\mathrm{N}$ gene expression by c-Jun and glucocorticoids: novel effects of Fos family members. Molecular Endocrinology 9 981-993.

Herman JP, Schafer MKH, Thompson RC \& Watson SJ 1992 Rapid regulation of corticotropin-releasing hormone gene transcription in vivo. Molecular Endocrinology 6 1061-1069.

Hill CS \& Treisman R 1995 Transcriptional regulation by target signals: mechanism and specificity. Cell 80 199-211.

Hirai S, Bourachot B \& Yaniv M 1990 Both Jun and Fos contribute to transcription activation by the heterodimer. Oncogene $\mathbf{5} 39-46$.

Hollenberg AN, Monden T, Flynn TR, Boers M, Cohen O \& Wondisford FE 1995 The human thyrotropin-releasing hormone is regulated by thyroid hormone through two distinct classes of negative response elements. Molecular Endocrinology 9 540-550.

Imai E, Miner JN, Mitchel JA, Yamamoto KR \& Granner DK 1993 Glucocorticoid receptor-cAMP response element-binding protein interaction and the response of the phosphoenol pyruvate carboxykinase gene to glucocorticoids. Fournal of Biological Chemistry $2685353-5356$

Joseph-Bravo P, Uribe RM, Vargas MA, Pérez-Martínez L, Zoeller RT \& Charli JL 1998 Multifactorial modulation of TRH metabolism. Cellular and Molecular Neurobiology 18 231-247.

Joseph-Bravo P, Pérez-Martínez L, Lezama L, Morales-Chapa C \& Charli JL 2002 An improved method for the expression of TRH in serum-supplemented primary cultures of fetal hypothalamic cells. Brain Research, Brain Research Protocols 9 93-104.

Kakucska I, Qi Y \& Lechan RM 1995 Changes in adrenal status affect hypothalamic thyrotropin-releasing hormone gene expression in parallel with corticotropin-releasing hormone. Endocrinology 136 2795-2802.

King BR, Smith R \& Nicholson RC 2002 Novel glucocorticoid and cAMP interactions on the CRH gene promoter. Molecular and Cellular Endocrinology 194 19-28.

Koller KJ, Wolf RS, Warden MK \& Zoeller RT 1987 Thyroid hormone regulates levels of thyrotropin-releasing hormone mRNA in the rat paraventricular nucleus. PNAS 84 7329-7333.

Kuwara S, Arima H, Bunno R, Sato I, Kondo N \& Oiso Y 2003 Regulation of vasopressin gene expression by cAMP and glucocorticoids in parvocellular neurons of the paraventricular nucleus in rat hypothalamic organotypic cultures. Fournal of Neuroscience 23 10231-10237.

Lechan RM \& Toni R 1992 Thyrotropin-releasing hormone neuronal system. In Neuroendocrinology, pp 279-330. Eds CB Nemeroff. Boca Raton: CRC Press.

Lee SL 1988 Structure of the gene encoding rat thyrotropin-releasing hormone. Fournal of Biological Chemistry 263 16604-16609.

Lee GC, Yang IM, Woo JT, Kim SW, Kim JW, Kim YS \& Choi YK 1996 Identification of glucocorticoid response element of the rat TRH gene. Korean Fournal of Internal Medicine 11 138-144.

Legradi G, Emerson CH, Ahima RS, Flier JS \& Lechan RM $1997 a$ Leptin prevents fasting-induced suppression of prothyrotropin-releasing hormone messenger ribonucleic acid in neurons of the hypothalamic paraventricular nucleus. Endocrinology 138 2569-2576.

Legradi G, Holzer D, Kapcala LP \& Lechan RM $1997 b$ Glucocorticoids inhibit stress-induced phosphorylation of CREB in corticotropin-releasing homone neurons of the hypothalamic paraventricular nucleus. Neuroendocrinology 66 86-97.

Lieberman BA, Bona BJ, Edwards DP \& Nordeen SK 1993 The constitution of a progesterone response element. Molecular Endocrinology 7 515-527.

Lucibello FC, Slater EP, Joos KU, Beato M \& Muller R 1990 Mutual transrepression of Fos and the glucocorticoid receptor: involvement of a functional domain in Fos which is absent in Fos B. EMBO fournal $92827-2834$.

Luo LG, Bruhn TO \& Jackson IMD 1995 Glucocorticoids stimulate thyrotropin-releasing hormone gene expression in cultured hypothalamic neurons. Endocrinology 136 4945-4950. 
McKeena NJ, Xu J, Nawaz Z, Tsai MJ \& O’Malley BW 1999 Nuclear receptor coactivators: multiple enzymes, multiple complexes, multiple functions. Fournal of Steroid Biochemistry and Molecular Biology 69 3-12.

Makara G \& Haller J 2001 Non-genomic effects of glucocorticoids in the neural system. Evidence, mechanisms and implications. Progress in Neurobiology 65 367-390.

Malkoski SP \& Dorin RI 1999 Composite glucocorticoid regulation at a functionally defined negative glucocorticoid response element of the human CRH gene. Molecular Endocrinology 13 1629-1644.

Malkoski SP, Handanos CM \& Dorin RI 1997 Localization of a negative glucocorticoid response element of the human corticotropin releasing hormone gene. Molecular and Cellular Endocrinology 127 189-199.

Maroder M, Farina AR, Vacca A, Felli MP, Meco D, Screpanti I, Frati L \& Gulino A 1993 Cell-specific bifunctional role of Jun oncogene family members on glucocorticoid receptor-dependent transcription. Molecular Endocrinology 7 570-584.

Masquillier D \& Sassone-Corsi P 1992 Transcriptional cross-talk: nuclear factors CREM and CREB bind to AP-1 sites and inhibit activation by Jun. Fournal of Biological Chemistry $\mathbf{2 6 7}$ 22460-22466.

Meyer ME, Gronemeyer H, Turcotte B, Bocquel MT, Tasset D \& Chambon P 1989 Steroid hormone receptors compete for factors that mediate their enhancer function. Cell $\mathbf{5 7} 433-442$.

Miner JF \& Yamamoto KR 1992 The basic region of AP-1 specifies glucocorticoid receptor activity at a composite element. Genes and Development 6 2491-2501

Newton R 2000 Molecular mechanisms of glucocorticoid action: what is important? Thorax $\mathbf{5 5}$ 603-613.

Nillni EA, Vaslet C, Harris M, Hollenberg A, Bjorbaek C \& Flier JS 2000 Leptin regulates prothyrotropin releasing hormone biosynthesis. Evidence for direct and indirect pathways. Fournal of Biological Chemistry 275 36124-36133.

Oki OH, Takahashi SI, Hidaka H \& Conti M 2000 Short term feedback regulation of cAMP in FRTL-5 thyroid cells. Fournal of Biological Chemistry 275 10831-10837.

Pedraza-Alva G, Zingg JM \& Jos JP 1994 AP-1 binds to a putative cAMP response element of the MyoDl promoter and negatively modulates MyoDl expression in dividing myoblasts. Fournal of Biological Chemistry 269 6978-6985.

Pérez-Martínez L, Carreón-Rodríguez A, González-Alzati ME, Morales C, Charli JL \& Joseph-Bravo P 1998 Dexamethasone rapidly regulates TRH mRNA levels in hypothalamic cell cultures: interaction with the cAMP pathway. Neuroendocrinology 68 345-354.

Pérez-Martínez L, Charli JL \& Joseph-Bravo P 2001 Development of pro-TRH gene expression in primary cultures of fetal hypothalamic cells. Developmental Brain Research 130 73-81.

Rangarajan PN, Umesono K \& Evans RM 1992 Modulation of glucocorticoid receptor function by protein kinase A. Molecular Endocrinology 6 1451-1457.

Renauld AE \& Spengler RN 2002 Tumor necrosis factor expressed by primary hippocampal neurons and $\mathrm{SH}-\mathrm{SY} 5 \mathrm{Y}$ cell is regulated by $\alpha_{2}$-adrenergic receptor activation. Fournal of Neuroscience Research $67264-274$

Rondel JM, de Greef WJ, van der Schoot P, Karels B, Klootwijk W \& Visser TH 1988 Effect of thyroid status and paraventricular area lesions on the release of thyrotropin-releasing hormone and catecholamines into hypophysial portal blood. Endocrinology 123 523-527.

Rutberg SE, Adams TL, Olive M, Alezander N, Vinson C \& Yuspa SH 1999 CRE DNA binding proteins bind to the AP-1 target sequence and suppress AP-1 transcriptional activity in mouse keratinocytes. Oncogene 18 1569-1579.

Sakar S, Legradi G \& Lechan RM 2002 Intracerebroventricular administration of alpha-melanocyte stimulating hormone increases phosphorylation of CREB in TRH- and CRH-producing neurons of the hypothalamic paraventricular nucleus. Brain Research $\mathbf{2 6}$ 50-59.

Sánchez E, Uribe RM, Corkidi G, Zoeller RT, Cisneros M, Zacarias M, Morales-Chapa C, Charli JL \& Joseph-Bravo P 2001 Differential responses of thyrotropin-releasing hormone (TRH) neurons to cold exposure or suckling indicate functional heterogeneity of the TRH system in the paraventricular nucleus in the rat hypothalamus. Neuroendocrinology 74 407-422.

Satoh T, Yamada M, Iwasaki T \& Mori M 1996 Negative regulation of the gene of preprothyrotropin-releasing hormone from the mouse by thyroid hormone requires additional factors in conjunction with thyroid hormone. Fournal of Biological Chemistry 271 27919-27926.

Satoh T, Monden T, Ishizuka T, Mitsuhashi T, Yamada M \& Mori M 1999 DNA binding and interaction with the nuclear receptor corepressor of thyroid hormone receptor are required for ligand-independent stimulation of the mouse preprothyrotropin-releasing hormone gene. Molecular and Cellular Endocrinology 154 137-149.

Schaaf MJM \& Cidlowski JA 2003 Molecular mechanisms of glucocorticoid action and resistance. Fournal of Steroid Biochemistry and Molecular Biology 83 37-48.

Schontal A, Herrlich P, Rahmsdorf HJ \& Ponta H 1988 Requirement for fos gene expression in the transcriptional activation of collagenase by other oncogenes and phorbol esters. Cell 54 325-334.

Schreiber E, Matthias P, Muller MM \& Schaffner W 1989 Rapid detection of octomer binding proteins with mini extracts prepared from a small number of cells. Nucleic Acids Research 176419.

Segerson TP, Hoefler H, Childers H, Wolfe HJ, Wu P, Jackson IM \& Lechan RM 1987a Localization of thyrotropin-releasing hormone prohormone messenger ribonucleic acid in rat brain by in situ hybridization. Endocrinology $12198-107$.

Segerson TP, Kauer J, Wolfe HC, Mobtaker H, Wu P, Jackson IM \& Lechan RM $1987 b$ Thyroid hormone regulates TRH biosynthesis in the paraventricular nucleus of the rat hypothalamus. Science 238 78-80.

Stauber C, Altschmied J, Akerblom IE, Marron JL \& Mellon PL 1992 Mutual cross-interference between glucocorticoid receptor and CREB inhibits transactivation in placental cells. New Biologist 4 527-540.

Tank AW \& Weiner N 1992 Induction of tyrosine hydroxylase by glucocorticoids in mouse neuroblastoma cells. Molecular Pharmacology 22 421-430.

Tavianini MA, Gkonos PJ, Lampe TH \& Roos BA 1989 Dexamethasone stimulates thyrotropin-releasing hormone production in a cell line. Molecular Endocrinology 3 605-610.

Uribe RM, Joseph-Bravo P, Pasten J, Ponce G, Méndez M, Covarrubias L \& Charli JL 1991 Some events of thyrotropin-releasing hormone metabolism are regulated in lactating and cycling rats. Neuroendocrinology 54 493-498.

Uribe RM, Redondo JL, Charli JL \& Joseph-Bravo P 1993 Suckling and cold stress rapidly and transiently increase TRH mRNA in the paraventricular nucleus. Neuroendocrinology 58 140-145.

Uribe RM, Pérez-Martínez L, Govarrubias L, Gómez O, Covarrubias L, Charli JL \& Joseph-Bravo P $1995 a$ Phorbol ester or cAMP enhance thyrotropin-releasing hormone mRNA in primary cultures of hypothalamic cells. Neuroscience Letters $\mathbf{2 0 1}$ $41-44$.

Uribe RM, Joseph-Bravo P \& Charli JL $1995 b$ Pups removal enhances thyrotropin-releasing hormone mRNA in the hypothalamic paraventricular nucleus. Fournal of Endocrinology 133 354-360.

Watters JJ, Campbell JS, Cunningham MJ, Krebs EG \& Dorsa DM 1997 Rapid membrane effects of steroids in neuroblastoma cells: effects of estrogen on mitogen activated protein kinase signaling cascade and c-fos immediate early gene transcription. Endocrinology $1384030-4033$ 
Whitehead D \& Carter DA 1997 cAMP response element-binding protein phosphorylation and DNA activity are increased in the anterior pituitary gland following glucocorticoid depletion. Fournal of Molecular Endocrinology 19 291-297.

Wilber JF \& Xu AH 1998 The thyrotropin-releasing hormone gene: cloning, characterization, and transcriptional regulation in the central nervous system, heart and testis. Thyroid $\mathbf{8}$ 897-901.

Yamada K, Duong DT, Scott DK, Wang JC \& Granner DK 1999 CGAAT/enhancer-binding protein $\beta$ is an accessory factor for the glucocorticoid response from the cAMP response element in the rat phosphoenolpyruvate carboxykinase gene promoter. Fournal of Biological Chemistry 274 5880-5887.
Yamada M, Radovick S, Wondisford FE, Nakayama Y, Weintraub BD \& Wilber JF 1990 Cloning and structure of human genomic DNA and hypothalamic cDNA encoding human preprothyrotropin-releasing hormone. Molecular Endocrinology 4 $551-555$.

Zoeller RT, Kabeer N \& Albers E 1990 Cold exposure elevates cellular levels of messenger ribonucleic acid encoding thyrotropin-releasing hormone in paraventricular nucleus despite elevated levels of thyroid hormones. Endocrinology 127 2955-2962.

Received 14 September 2004 Accepted 4 October 2004 